\title{
Extension of The Improved Upper-Bound Pushover Analysis For Seismic Assessment of Steel Moment Resisting Frames With Setbacks
}

\section{Abdallah Yacine Rahmani ( $\nabla$ ayacinerahmani26@yahoo.com )}

University of M'sila: Universite de M'sila https://orcid.org/0000-0002-5095-2814

\section{Mohamed Badaoui}

Ziane Achour University of Djelfa: Universite Ziane Achour de Djelfa

\section{Nouredine Bourahla}

National Polytechnic of Algeria: Ecole Nationale Polytechnique

\section{Rita Bento}

Universidade de Lisboa Instituto Superior Técnico: Universidade de Lisboa Instituto Superior Tecnico

\section{Research Article}

Keywords: setbacks buildings, nonlinear static procedures, improved upper-bound, pushover analysis, lateral load distribution

Posted Date: December 28th, 2021

DOI: https://doi.org/10.21203/rs.3.rs-1197067/v1

License: (9) This work is licensed under a Creative Commons Attribution 4.0 International License. Read Full License 


\title{
Extension of the improved upper-bound pushover analysis for seismic assessment of steel moment resisting frames with setbacks
}

\author{
Abdallah Yacine Rahmani ${ }^{\text {a,b,* }}$, Mohamed Badaoui ${ }^{\text {c }}$, Nouredine Bourahla ${ }^{a}$, Rita Bento ${ }^{\mathrm{d}}$ \\ ${ }^{a}$ Earthquake Engineering and Structural Dynamics Laboratory, National Polytechnic School, Algiers, Algeria. \\ b Department of Civil Engineering, University of Msila, M'sila 28000, Algeria. \\ c Laboratory of Mechanics and Materials Development at the University of Djelfa, Djelfa 17000, P.O.B. 3117 - \\ Algeria.

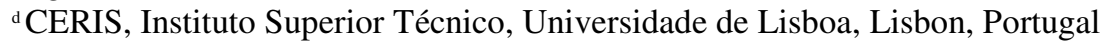

\begin{abstract}
Pushover analysis technique is a key tool for the performance-based seismic design that has been largely adopted in the new generation of seismic codes. Therefore, more precise and reliable performance predictions are highly demanded. Improved upper-bound (IUB) pushover analysis is one of the advanced nonlinear static procedures (NSPs) that has been recently developed. This procedure estimates adequately the response of regular and tall buildings. In this study, IUB is extended to assess the seismic response of irregular buildings with setbacks. To this end, an adjustment of the IUB lateral load distribution is implemented by integrating a third mode of vibration to control the response of these complex buildings. Fifteen multi-storey steel frames with different types of setbacks including a reference structure are used to test the accuracy of the proposed procedure by comparing its results to those from other NSPs and the nonlinear time history analysis (NLHA). The findings show the superior capacity of the extended IUB in predicting the seismic response of buildings with different levels and types of setbacks.
\end{abstract}

Keywords: setbacks buildings; nonlinear static procedures; improved upper-bound; pushover analysis; lateral load distribution.

\section{Introduction}

The trend in adopting the concept of performance-based design in seismic codes requires efficient analysis techniques capable of assessing the seismic performance of large variety of building configurations. NSPs are among the most favourite alternatives to perform such tasks. Although, several developments have been achieved to enhance the capabilities of this procedure, still challenging issues need to be addressed. One of the most common and frequent irregularities in buildings that a designer may face is setbacks when an abrupt discontinuity in the vertical geometry of the building exists. These discontinuities affect considerably the seismic performance of the buildings. Several researchers have studied the behaviour of setback buildings ((Humar and Wright 1977; Aranda 1984; Shahrooz and Moehle 1990; Wood 1992; Wong and Tso 1994; Pinto and Costa 1995; Mazzolani and Piluso 1996; Bosco et al. 2002; Das and Nau 2003; Romão et al. 2004; Lignos and Gantes 2005; Athanassiadou 2008; Sarkar et al. 2010). A conflict was observed in their conclusions about the setback effects on the global and local behaviour of structures. For that, deeper research work is still needed to resolve conflicting results about the seismic behaviour of this type of building structures. The nonlinear time history analysis (NLTH) can be the first choice to estimate their seismic responses. However, some needed qualification issues are beyond the engineering competency level.

\footnotetext{
${ }^{*}$ Corresponding author: Ph.D

Email address: abdallahyacine.rahmani@univ-msila.dz (A. Y. Rahmani)
} 
The nonlinear static procedures (NSPs) or pushover analyses, still be a good alternative to the sophisticated nonlinear time history analysis, especially after their development to assess complex structural behaviour. The conventional version of pushover analysis considers the inelastic behaviour accurately when the elastic fundamental (first) mode controls the response of the structure during the analysis (Freeman 1998; Fajfar 1999). This supposition may give good results for regular structures, but where higher modes affect the structural response, like in highrise or irregular buildings, this assumption leads to inadequate results.

Several researchers have tried to overcome this limitation. The modal pushover analysis (MPA) developed by Chopra and Goel (Chopra and Goel 2002) is one of the most common and known methods. In this multi-run procedure, the few first modes of vibration, which have a significant effect on the structural response, are considered. In each run of the MPA procedure, a modal distribution corresponds to the ith-mode of vibration is applied to the structure. The final response is obtained by combining (using SRSS or CQC rule) the results from each modal run. This method was improved and extended to assess the seismic response of irregular buildings and bridges (Chopra and Goel 2004; Mao et al. 2008; Paraskeva and Kappos 2010; Reyes and Chopra 2011; Belejo and Bento 2016).

Consistently, Jan et al. (Jan et al. 2004) developed an upper bound (UB) pushover procedure to take the higher modes effect into account by considering only the two first modes of vibration. The UB procedure uses the absolute sum modal combination to calculate both the lateral load pattern and the target displacement. The Authors studied a set of two-dimensional tall building frames and they concluded that the UB gives good results for flexible buildings. However, it is noticeable for most of the studied cases that the procedure underestimates the response at lower storeys. Poursha et al. (Poursha and Samarin 2015) have modified and extended the UB method (MUB and EUB) to overcome its shortcomings. In the two new procedures, the results of the conventional and the UB procedures are combined to get the final responses of buildings. However, the target displacement is considered equal to the mean of the roof displacements calculated by the NTHA, which makes the two multi-run procedures difficult to be applied in practice. Later, Rahmani et al. (Rahmani et al. 2018) proposed the so-called improved upper bound (IUB) pushover analysis. The IUB procedure adjusts the contribution of the second mode of vibration in both the lateral load pattern and the target displacement formulas using a correction factor. The corrected applied load pattern has been combined with the scaled uniform and first mode lateral patterns to get the final (envelope) lateral load distribution. IUB procedure gives good results for seismic assessment of tall steel building frames compared to the MUB results and other pushover procedures. El-Esnawy et al. (El-Esnawy et al. 2020) confirm this conclusion.

The conventional N2 method (Fajfar 1999) was also improved to consider the higher mode effects (Fajfar et al. 2005; Kreslin and Fajfar 2011b, a). To overcome the negligence of higher mode effects, Fajfar and his team proposed an extended version of the original N2 method. The results of the N2 procedure are adjusted through correction factors based on the linear dynamic response spectrum analysis. Recently, Zarrin et al. (Zarrin et al. 2021a) have proposed a multimode N2 (MN2) method to assess the seismic performance of jacket-type offshore platforms. MN2 method employs the algebraic sum combination rule to calculate the modal response for the linear dynamic response spectrum analysis instead of the quadratic modal combination rule used in the extended N2 method. 
In 2009, a consecutive modal pushover (CMP) procedure was developed by Poursha et al. (Poursha et al. 2009) for assessing the seismic response of high-rise buildings. The method is based on enveloping the results obtained from single-stage and multi-stage pushover analyses. The single-stage pushover analysis is used to control the lower stories responses of tall buildings when the multi-stage procedure controls the seismic demands at mid and upper stories. Khoshnoudian and Kiani (Khoshnoudian and Kiani 2012) modified the CMP method to study the seismic response of one-way asymmetric-plan tall buildings. Poursha et al. (Poursha et al. 2014) extended the CMP method to investigate the effects of higher modes (torsion) in the seismic behaviour of two-way asymmetric-plan high-rise buildings that were subjected to bidirectional seismic ground motions. Recently, Zarrin et al. (Zarrin et al. 2021b) developed an updated consecutive modal pushover (UCMP) procedure. The new procedure was applied to two case study jacket offshore platforms models.

A single-run multi-mode pushover (SMP) procedure was developed by Poursha and Amini (Poursha and Amini 2015). The authors calculated the lateral load pattern from the algebraic summation of the modal storey forces. In another study, Behnamfar et al. (Behnamfar et al. 2016) enhanced the work of Sahraei and Behnamfar (Sahraei and Behnamfar 2014) that based on the storey drift to construct the lateral load vector. In the extended version, a new combination rule is employed to combine the modal drifts instead of using the square-root-of-sum-of the squares (SRSS). Liu and Kuang (Liu and Kuang 2017) developed the so-called spectrum-based pushover analysis (SPA) to assess the seismic behaviour of tall buildings. In this procedure, both the lateral load vector and the target displacement are computed based on the modal response analysis. Later, the SPA procedure was used to study several types of buildings (Liu et al. 2018, 2020).

Through a simplified procedure, Guan et al. (Guan et al. 2019) suggested calculating the structural seismic response by combining the responses obtained from three conventional pushover analyses with different lateral load distributions, including the uniform, the first mode and the concentrated distributions loadings. In the same context, Habibi et al. (Habibi et al. 2019) proposed a conventional method with optimal lateral load pattern obtained using an optimisation procedure.

On another issue, several authors devised adaptive pushover analyses in an attempt to consider the influence of the damage and the stiffness degradation as well as the higher mode effects by updating the applied load patterns in each phase during the nonlinear loading (Bracci et al. 1997a; Elnashai 2001; Antoniou and Pinho 2004a, b; Kalkan and Kunnath 2006a; Shakeri et al. 2010a, 2013; Abbasnia et al. 2014a, b; Tarbali and Shakeri 2014; Amini and Poursha 2017; Sürmeli and Yüksel 2018; Rahmani et al. 2019b; Jalilkhani et al. 2020). Indeed, these procedures made the pushover analysis more complex and hard to apply in practice (Kreslin and Fajfar 2011a).

Most of the above-mentioned studies have examined the behaviour of tall, regular buildings. Only a few of them used setback buildings in their investigations. Among the few studies, there is a recent study conducted by Bohlouli and Poursha (Bohlouli and Poursha 2016). The authors studied a set of setback steel moment-resisting frames. Four advanced pushover procedures are used in this investigation, and according to the results, the accuracy of these procedures is influenced by the geometrical configuration of the setback frames. Also, Rooshenas (Rooshenas 2020) highlighted the topic of seismic behaviour of tall concrete structures partially infilled with masonry panels. In this study, results from different pushover procedures are compared. The author concluded that both the higher modes effect and the infill panels should be considered when analysing this type of buildings. 
In the present work, the improved upper-bound (IUB) is extended to account for the setback effect on the seismic response of mid-rise buildings. In addition to the two first modes of vibration that are used in IUB method, a third mode of vibration is employed to generate the applied load vector. The performance of the proposed extended IUB version is applied to fifteen 10 -storey buildings with different setback configurations including a reference structure. The results in terms of target displacement, storey displacements and storey drift are compared with those from other pushover procedures as well as the nonlinear time history analysis NTHA as a benchmark.

\section{Lateral load patterns development}

\subsection{UB lateral load pattern}

Jan et al. (Jan et al. 2004) hypothesised that only the two first modes of vibration have a significant impact on the seismic demand of structures in their original UB version. The influence of the other higher modes is then negligible. The UB load pattern can be written as follows:

$$
\mathbf{f}_{\boldsymbol{U} \boldsymbol{B}}=\omega_{1}^{2} \mathbf{M} \boldsymbol{\varphi}_{\mathbf{1}}+\omega_{2}^{2} \mathbf{M} \boldsymbol{\varphi}_{\mathbf{2}}\left(\frac{q_{2}}{q_{1}}\right)_{U B}
$$

In which $\omega_{1}$ and $\omega_{2}$ are the natural frequencies for the first and second mode, respectively; $\mathbf{M}$ is the mass matrix; $\boldsymbol{\varphi}_{\mathbf{1}}$ and $\boldsymbol{\varphi}_{\mathbf{2}}$ are the first two normalised mode shapes and $q_{1}, q_{2}$ the modal coordinates of the first two modes, respectively (Jan et al. 2004). The $\left(q_{2} / q_{1}\right)$ can be calculated using the following equation:

$$
\left(\frac{q_{2}}{q_{1}}\right)_{U B}=\left|\frac{\Gamma_{2} S_{d 2}}{\Gamma_{1} S_{d 1}}\right|
$$

where $\Gamma_{1}, \Gamma_{2}$ are the modal participation factors of the first two modes of vibration and $S_{d 1}, S_{d 2}$ are the displacements obtained from the elastic displacement response spectrum.

The main conclusion of Jan et al. (Jan et al. 2004) in their study is that the use of the UB lateral load distribution underestimates the seismic response at lower stories in high-rise buildings.

\subsection{IUB lateral load pattern}

To overcome the shortcoming of the UB pushover analysis, Rahmani et al. (Rahmani et al. 2018) proposed a new version of the UB method called the improved UB pushover analysis. In this version, the authors adjusted the contribution of the second mode of vibration in the load pattern formula using a correction factor $C_{r}$.

$$
\mathbf{f}_{\boldsymbol{U} \boldsymbol{B}}^{\prime}=\omega_{1}^{2} \mathbf{M} \boldsymbol{\varphi}_{\mathbf{1}}+C_{r}\left(\omega_{2}^{2} \mathbf{M} \boldsymbol{\varphi}_{\mathbf{2}}\left(\frac{q_{2}}{q_{1}}\right)_{U B}\right)
$$

It has been found that the value of the correction factor is close to 0.5 based on an optimisation approach (Rahmani et al. 2018). Recently, Fujii (Fujii 2019) confirmed this value. Hence, the expression of the lateral load pattern can be obtained by: 
$\mathbf{f}_{\boldsymbol{U} \boldsymbol{B}}^{\prime}=\omega_{1}^{2} \mathbf{M} \boldsymbol{\varphi}_{\mathbf{1}}+0.5 \cdot\left(\omega_{2}^{2} \mathbf{M} \boldsymbol{\varphi}_{\mathbf{2}}\left(\frac{q_{2}}{q_{1}}\right)_{U B}\right)$

The improved UB lateral load pattern $\mathbf{f}_{I U B}$ is defined as the envelope load pattern of the three lateral load patterns (uniform $\mathbf{f}_{\boldsymbol{U n i f}}$, first mode $\mathbf{f}_{\mathbf{1} \boldsymbol{M}}$ and the corrected upper bound load $\mathbf{f}_{\boldsymbol{U} \boldsymbol{B}}^{\prime}$ distributions). To get a single-run procedure, the three load vectors are combined, with an envelope lateral load pattern capable of controlling both seismic responses at lower and upper storeys of buildings (Rahmani et al. 2018).

$\mathbf{f}_{\text {Unif }}$ represents the uniform load pattern:

$\mathbf{f}_{\text {Unif }}=r_{u} \omega_{1}^{2} \mathbf{M 1}$

$\mathrm{r}_{\mathrm{u}}$ is set equal to 0.8 to ensure that the uniform load distribution is dominant at lower and mid storeys (Rahmani et al. 2018). 1 is a unity vector.

The first mode load pattern $\mathbf{f}_{\mathbf{1 M}}$ can be obtained by

$$
\mathbf{f}_{\mathbf{1} \boldsymbol{M}}=\omega_{1}^{2} \mathbf{M} \boldsymbol{\varphi}_{\mathbf{1}}
$$

Finally, the value of the applied load pattern at the ith floor $\mathbf{f}_{\boldsymbol{i}, I U B}$ can be given by:

$$
\mathbf{f}_{i, I U B}=\max \left(\mathbf{f}_{i, U B}^{\prime}, \mathbf{f}_{i, \mathbf{1} M}, \mathbf{f}_{i, \text { Unif }}\right)
$$

\subsection{Extended IUB lateral load pattern}

In this novel approach, the contribution of the $3^{\text {rd }}$ mode of vibration is considered. According to the study of Davoudi et al. (Davoudi et al. 2016), the applied lateral load $\boldsymbol{f}$ can be written as:

$\boldsymbol{f}=0.48 \boldsymbol{f}_{m 1} \pm 0.26 \boldsymbol{f}_{m 2} \pm 0.26 \boldsymbol{f}_{m 3}$

$\boldsymbol{f}_{\boldsymbol{m} \mathbf{1}}, \boldsymbol{f}_{\boldsymbol{m} \mathbf{2}}$ and $\boldsymbol{f}_{\boldsymbol{m} 3}$ are the load vectors of the first, the second and the third modes of vibration, respectively. If the modal loads are substituted by their corresponding formulas in Eq. 8, it becomes

$\boldsymbol{f}=0.48\left(\omega_{1}^{2} \mathbf{M} \boldsymbol{\varphi}_{1} q_{1}\right) \pm 0.26\left(\omega_{2}^{2} \mathbf{M} \boldsymbol{\varphi}_{2} q_{2}\right) \pm 0.26\left(\omega_{3}^{2} \mathbf{M} \boldsymbol{\varphi}_{3} q_{3}\right)$

In which $\omega_{3}, \boldsymbol{\varphi}_{3}$ and $q_{3}$ are the natural frequency, the normalised mode shape, and the modal co-ordinate of the $3^{\text {rd }}$ mode of vibration, respectively. Multiplying and dividing by the factor $0.48 \mathrm{q}_{1}$, then Eq. (9) can be expressed as:

$\boldsymbol{f}=0.48 q_{1}\left[\left(\omega_{1}^{2} \mathbf{M} \boldsymbol{\varphi}_{1}\right) \pm \frac{0.26}{0.48}\left(\omega_{2}^{2} \mathbf{M} \boldsymbol{\varphi}_{2} \frac{q_{2}}{q_{1}}\right) \pm \frac{0.26}{0.48}\left(\omega_{3}^{2} \mathbf{M} \boldsymbol{\varphi}_{3} \frac{q_{3}}{q_{1}}\right)\right]$

Because the applied load in pushover analysis starts from zero, the $0.48 q_{1}$ factor has no influence on the load distribution, therefore Eq. (10) may be stated (using simply the plus sign) as follows: 
$\boldsymbol{f}^{\prime}=\left[\left(\omega_{1}^{2} \mathbf{M} \boldsymbol{\varphi}_{1}\right)+\frac{0.26}{0.48}\left(\omega_{2}^{2} \mathbf{M} \boldsymbol{\varphi}_{2} \frac{q_{2}}{q_{1}}\right)+\frac{0.26}{0.48}\left(\omega_{3}^{2} \mathbf{M} \boldsymbol{\varphi}_{\mathbf{3}} \frac{q_{3}}{q_{1}}\right)\right]$

The ratio $0.26 / 0.48$ is considered here as a correction factor $C_{r}$ to adjust the contribution of the second and third modes of vibration. Its value is given by

$$
C_{r}=\frac{0.26}{0.48} \approx 0.5
$$

In this study, and based on this assumption, the upper-bound load vector $\mathbf{f}_{\boldsymbol{U} \boldsymbol{B}}^{\prime \prime}$ is given by

$$
\mathbf{f}_{U \boldsymbol{B}}^{\prime \prime}=\boldsymbol{f}^{\prime}=\omega_{1}^{2} \mathbf{M} \boldsymbol{\varphi}_{\mathbf{1}}+0.5 \cdot\left(\omega_{2}^{2} \mathbf{M} \boldsymbol{\varphi}_{\mathbf{2}}\left(\frac{q_{2}}{q_{1}}\right)_{U B}\right)+0.5 \cdot\left(\omega_{3}^{2} \mathbf{M} \boldsymbol{\varphi}_{\mathbf{3}}\left(\frac{q_{3}}{q_{1}}\right)_{U B}\right)
$$

and,

$$
\left(\frac{q_{3}}{q_{1}}\right)_{U B}=\left|\frac{\Gamma_{3} S_{d 3}}{\Gamma_{1} S_{d 1}}\right|
$$

The final lateral load pattern $\mathbf{f}_{\boldsymbol{E} I \boldsymbol{B} \boldsymbol{B}}$ is defined as the envelope load pattern of the only two lateral load patterns (uniform $\mathbf{f}_{\boldsymbol{U} \text { nif }}$, and the corrected upper bound load $\mathbf{f}_{\boldsymbol{U} \boldsymbol{B}}^{\prime \prime}$ distributions). The ith value of the applied load pattern at the ith floor $\mathbf{f}_{\boldsymbol{i}, \boldsymbol{E I U B}}$ becomes:

$$
\mathbf{f}_{i, E I U B}=\max \left(\mathbf{f}_{\boldsymbol{i}, \boldsymbol{U B}}^{\prime \prime}, \mathbf{f}_{\boldsymbol{i}, \boldsymbol{U n i f}}\right)
$$

\section{The target displacement}

The target displacement in UB pushover method (Jan et al. 2004) at the roof of the structure $U_{r}$ is determined as follows:

$U_{r}=U_{r T L P}\left(1+\left(\frac{q_{2}}{q_{1}}\right)_{U B}\right)$

Where $U_{r T L P}$, the target displacement at the building's roof, is calculated using the capacity spectrum method (CSM) described in ATC-40 (ATC-40 1996) by applying a triangular inverted load pattern. IUB adopted the same correction factor $C_{r}$ used in the lateral load pattern to adjust the target displacement of the UB procedure, and the formula becomes:

$U_{r}=U_{r M 1}\left(1+\left(\frac{q_{2}}{q_{1}}\right)_{U B} C_{r}\right)$

Because the first mode load distribution must also be established in the IUB's phases, the triangle load pattern is replaced by the first mode load pattern to compute the target displacement $U_{r M 1}$ in the above equation. By adding the contribution of the third mode, the formula of the target displacement for the EIUB procedure is given by:

$U_{r}=U_{r M 1}\left(1+\left(\frac{q_{2}}{q_{1}}\right)_{U B} C_{r}+\left(\frac{q_{3}}{q_{1}}\right)_{U B} C_{r}\right)$ 
For both equations (17) and (18), the correction factor $C_{r}$ is equal to 0.5

\section{Summary of the EIUB procedure}

EIUB follows the same steps as the IUB procedure (Rahmani et al. 2018). The major difference is the use of equation (15) instead of equation (7) when determining the applied lateral load vector, and the equation (18) to calculate the target displacement. The EIUB procedure can be summarised in the following steps:

1. Calculate the natural frequencies of the structure, $\omega_{n}$, and the mode-shapes $\boldsymbol{\varphi}_{n}$, such that the lateral component of $\boldsymbol{\varphi}_{n}$ at the roof equals unity.

2. Determine the upper-bound of the contribution of $2^{\text {nd }}$ and $3^{\text {rd }}$ modes $\left(q_{i} / q_{1}\right)_{U B}$ as provided by Eqs. (2) and (14), respectively, using the elastic response spectrum of the specified earthquake records.

3. Calculate the lateral load distribution vector across the building's height using Eq. (15).

4. Determine the target roof displacement $U_{r}$ using Eq. (18) or Eq (17).

5. Use the lateral load determined in step 3 to perform a pushover analysis until the target displacement estimated in step 4 is reached.

6. Determine the maximum values of the seismic responses from the single-run analysis (step 5).

The contribution of the different load patterns in the final applied load pattern of each approach (UB, IUB and EIUB) is summarised in Table 1.

Table 1. Summary of UB, IUB and EIUB applied load patterns

\begin{tabular}{|c|c|c|c|}
\hline Contribution & UB & IUB & EIUB \\
\hline $\begin{array}{l}1^{\text {st }} \text { mode load } \\
\text { pattern }\end{array}$ & $\omega_{1}^{2} m \varphi_{1}$ & $\omega_{1}^{2} m \varphi_{1}$ & $\omega_{1}^{2} m \varphi_{1}$ \\
\hline $\begin{array}{l}\text { Uniform load } \\
\text { pattern }\end{array}$ & - & $r_{u} \omega_{1}^{2} m_{i}$ & $r_{u} \omega_{1}^{2} m_{i}$ \\
\hline $\begin{array}{l}\text { Higher modes } \\
\text { load pattern }\end{array}$ & $\omega_{2}^{2} m \varphi_{2}\left(\frac{q_{2}}{q_{1}}\right)_{U B}$ & $\omega_{2}^{2} m \varphi_{2}\left(\frac{q_{2}}{q_{1}}\right)_{U B} . C_{r}$ & $\begin{array}{l}\omega_{2}^{2} m \varphi_{2}\left(\frac{q_{2}}{q_{1}}\right)_{U B} \cdot C_{r} \\
+\omega_{3}^{2} m \varphi_{3}\left(\frac{q_{3}}{q_{1}}\right)_{U B} \cdot C_{r}\end{array}$ \\
\hline Combination & $\begin{array}{l}\omega_{1}^{2} m \varphi_{1} \\
+\omega_{2}^{2} m \varphi_{2}\left(\frac{q_{2}}{q_{1}}\right)_{U B}\end{array}$ & $\begin{array}{l}\max \left(\omega_{1}^{2} m \varphi_{1}, r_{u} \omega_{1}^{2} m_{i}, \omega_{1}^{2} m \varphi_{1}\right. \\
\left.+\omega_{2}^{2} m \varphi_{2}\left(\frac{q_{2}}{q_{1}}\right)_{U B} . C_{r}\right)\end{array}$ & $\begin{array}{l}\max \left(r_{u} \omega_{1}^{2} m_{i}, \omega_{1}^{2} m \varphi_{1}\right. \\
+\omega_{2}^{2} m \varphi_{2}\left(\frac{q_{2}}{q_{1}}\right)_{U B} . C_{r} \\
\left.+\omega_{3}^{2} m \varphi_{3}\left(\frac{q_{3}}{q_{1}}\right)_{U B} . C_{r}\right)\end{array}$ \\
\hline $\begin{array}{l}\text { Target } \\
\text { displacement }\end{array}$ & $U_{r T L P}\left(1+\left(\frac{q_{2}}{q_{1}}\right)_{U B}\right)$ & $U_{r M 1}\left(1+\left(\frac{q_{2}}{q_{1}}\right)_{U B} C_{r}\right)$ & $\begin{aligned} U_{r}= & U_{r M 1}(1+ \\
& \left(\frac{q_{2}}{q_{1}}\right)_{U B} C_{r}+ \\
& \left.\left(\frac{q_{3}}{q_{1}}\right)_{U B} C_{r}\right)\end{aligned}$ \\
\hline
\end{tabular}

\section{Numerical Analyses}

\subsection{Description of the studied structures}

Fifteen two-dimensional (2D) 10-storey moment-resisting frames were used to validate the proposed procedure. This includes one reference regular frame selected from the literature [35], 
and fourteen frames with vertical irregularity generated by introducing setbacks in the reference regular frame. Setbacks occur at various elevations of the buildings. All the structures are threebay frames. The bays are $5 \mathrm{~m}$ long, with a consistent floor height of $3.2 \mathrm{~m}$. The configuration of the frames is shown in Fig 2. Three two-digit numbers following the F letter (the letter F stands for frame) in the frame's name represent the number of storeys in each bay of the frame from left to right, respectively. All of the fourteen setback structures present a certain level of geometrical irregularity. The gravity loads were equal to 6.50 and $2.00 \mathrm{kN} / \mathrm{m}^{2}$ for the dead and live loads, respectively. Tables 2 and 3 exhibit section details of the structures under study (Fig 2). Reference (Behnamfar et al. 2016) provides further information on the reference structure.

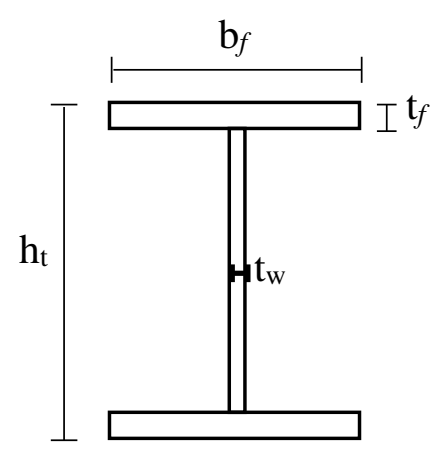

(a)

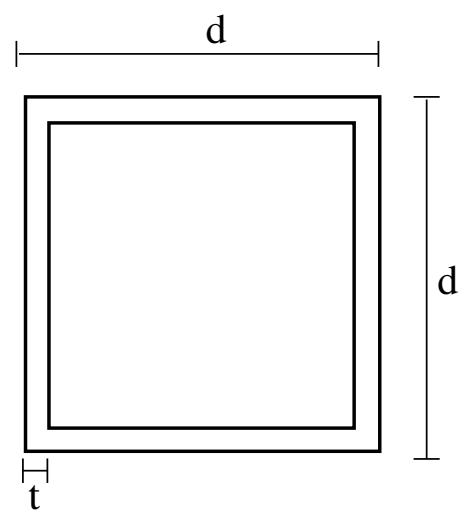

(b)

Fig. 1. Types of used sections, (a) beams, (b) columns (Behnamfar et al. 2016)
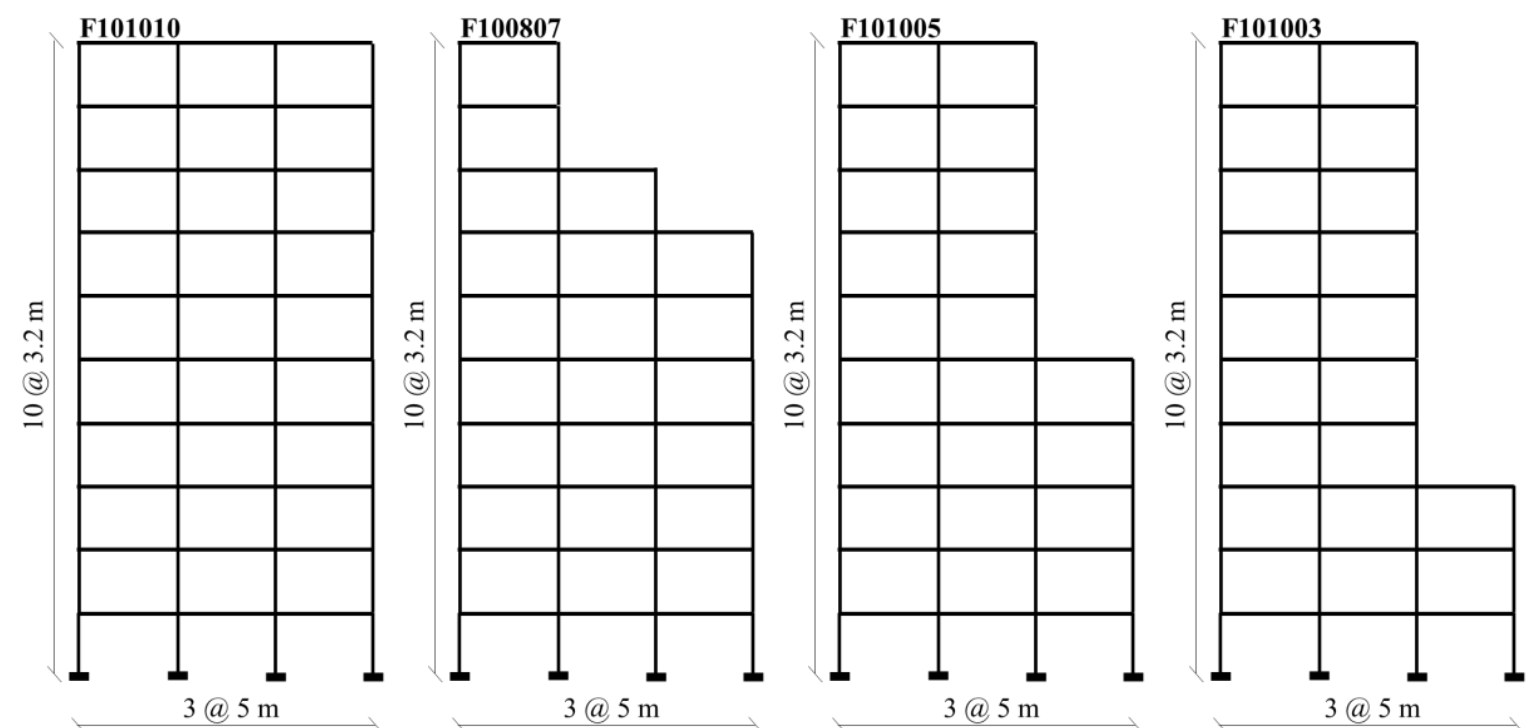

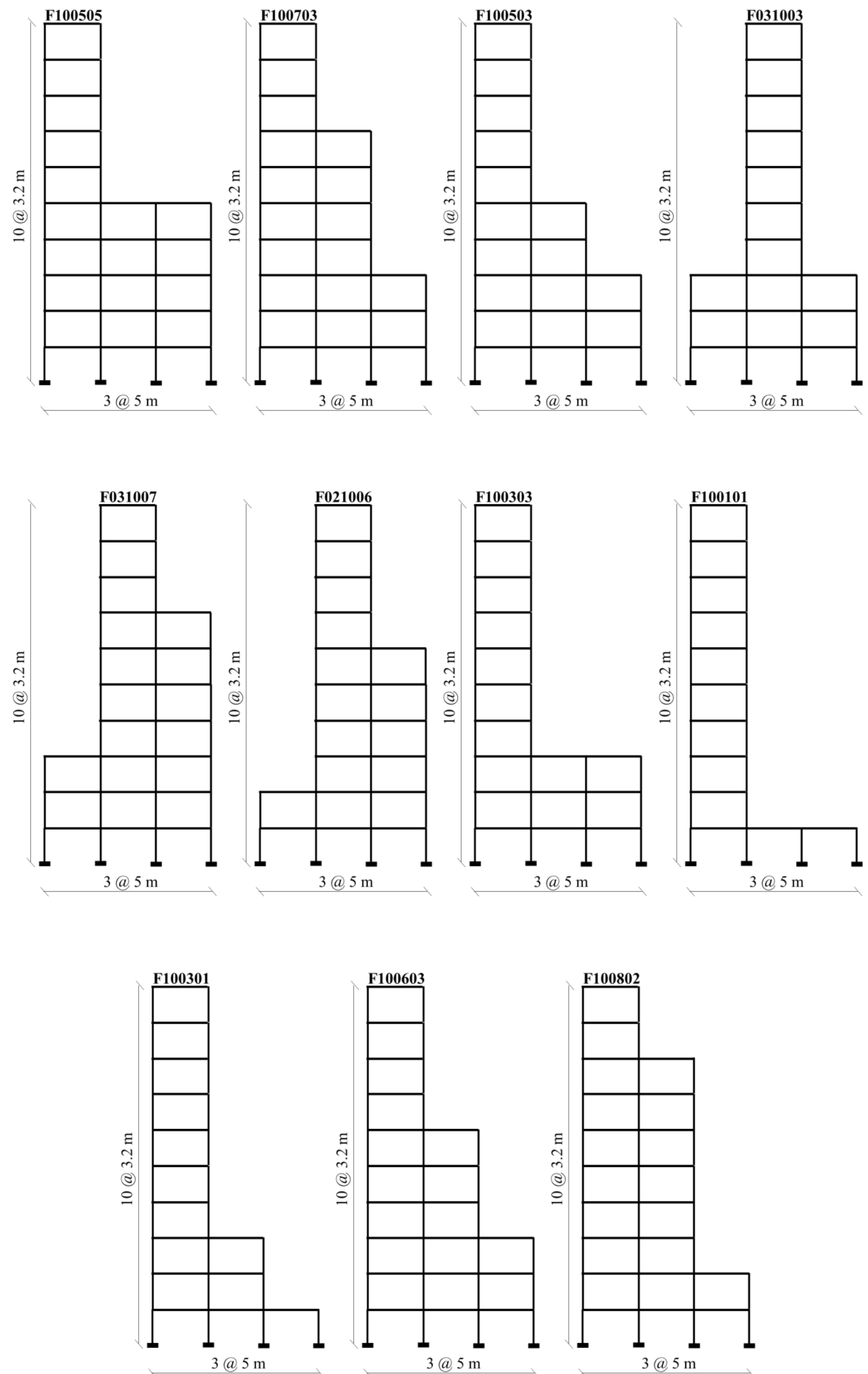

Fig. 2. Geometric configurations of the steel frames. 
Table 2. Section details of the beams and columns for the studied frames

\begin{tabular}{cccccccc}
\hline & \multicolumn{3}{c}{ Dimensions of beams } & \multicolumn{4}{c}{ Dimensions of columns } \\
\hline Section & $\mathrm{h}_{\mathrm{t}}(\mathrm{cm})$ & $\mathrm{t}_{\mathrm{w}}(\mathrm{cm})$ & $\mathrm{b}_{f}(\mathrm{~cm})$ & $\mathrm{t}_{f}(\mathrm{~cm})$ & Section & $\mathrm{d}(\mathrm{cm})$ & $\mathrm{t}(\mathrm{cm})$ \\
\hline B1 & 40 & 1 & 22.5 & 2 & C1 & 35 & 2.5 \\
B2 & 35 & 0.88 & 22.5 & 2 & C2 & 30 & 2 \\
B3 & 30 & 0.8 & 20 & 1.5 & & & \\
\hline
\end{tabular}

Table 3. Beams and columns of the studied frames

\begin{tabular}{lcccc}
\hline Building & Storeys & Columns & Beams & $\begin{array}{c}\text { Mechanical } \\
\text { properties }\end{array}$ \\
\hline \multirow{4}{*}{ 10-storey } & $1-4$ & $\mathrm{C} 1$ & $\mathrm{~B} 1$ & $F_{y}=235 \mathrm{MPa}$ \\
& $5-6$ & $\mathrm{C} 1$ & $\mathrm{~B} 2$ & $E=200 \mathrm{GPa}$ \\
& $7-8$ & $\mathrm{C} 2$ & $\mathrm{~B} 2$ & \\
\hline
\end{tabular}

E -Young Modulus; $F_{y}-$ steel yield stress

\subsection{Ground motion records selection}

The nonlinear time history analysis and the static non-linear procedures were performed using a set of twenty-one ground motion records. The records were chosen from records on soil Type C that were compatible with the design assumptions of the structures under study, with magnitudes ranging from 6 to 7.5. All the data comes from the strong-motion database of the PEER (Pacific Earthquake Engineering Research Center) (2021). Figure 3 depicts the elastic spectra of the selected ground motion records (with a damping ratio of $5 \%$ ), as well as the target spectrum (design spectrum) for the $\mathrm{F} 100505$ frame. In the time range of $0.2 \mathrm{~T}_{1}$ to $2 \mathrm{~T}_{1}\left(\mathrm{~T}_{1}\right.$ is the period of the first mode of vibration of the studied building), there is a satisfactory match between the geometric mean spectrum of the chosen records and the target spectrum. It is worth noting that for any time within the specified period range, the average spectrum of the individual spectra does not fall below 90\% of the target response spectrum (ASCE 2016). Table 4 lists other characteristics of the selected ground motion data.

Table 4. Details of the ground motion records

\begin{tabular}{clclcc}
\hline ID & Earthquake Name & Year & \multicolumn{1}{c}{ Station Name } & Magnitude & $\begin{array}{c}\text { Distance } \\
(\mathbf{k m})\end{array}$ \\
\hline $\mathbf{1}$ & Parkfield & 1966 & Cholame - Shandon Array \#8 & 6.19 & 12.9 \\
$\mathbf{2}$ & Imperial Valley-06 & 1979 & Delta & 6.53 & 22.03 \\
$\mathbf{3}$ & Imperial Valley-06 & 1979 & El Centro Array \#12 & 6.53 & 17.94 \\
$\mathbf{4}$ & Victoria_Mexico & 1980 & SAHOP Casa Flores & 6.33 & 39.1 \\
$\mathbf{5}$ & Morgan Hill & 1984 & Gilroy Array \#3 & 6.19 & 13.01 \\
$\mathbf{6}$ & Chalfant Valley-02 & 1986 & Bishop - LADWP South St & 6.19 & 14.38 \\
$\mathbf{7}$ & Superstition Hills-02 & 1987 & Brawley Airport & 6.54 & 17.03 \\
$\mathbf{8}$ & Superstition Hills-02 & 1987 & El Centro Imp. Co. Cent & 6.54 & 18.2 \\
$\mathbf{9}$ & Landers & 1992 & Desert Hot Springs & 7.28 & 21.78 \\
$\mathbf{1 0}$ & Landers & 1992 & Mission Creek Fault & 7.28 & 26.96 \\
$\mathbf{1 1}$ & Big Bear-01 & 1992 & San Bernardino & 6.46 & 33.56 \\
$\mathbf{1 2}$ & Kobe_Japan & 1995 & Abeno & 6.9 & 24.85 \\
$\mathbf{1 3}$ & Kobe_Japan & 1995 & Sakai & 6.9 & 28.08 \\
$\mathbf{1 4}$ & Gulf of Aqaba & 1995 & Eilat & 7.2 & 43.29 \\
$\mathbf{1 5}$ & Duzce_Turkey & 1999 & Bolu & 7.14 & 12.02 \\
$\mathbf{1 6}$ & Tottori_Japan & 2000 & TTR006 & 6.61 & 35.15 \\
\hline
\end{tabular}




\begin{tabular}{llllcc}
\hline $\mathbf{1 7}$ & El Mayor-Cucapah_Mexico & 2010 & Chihuahua & 7.2 & 18.21 \\
$\mathbf{1 8}$ & El Mayor-Cucapah_Mexico & 2010 & MICHOACAN DE OCAMPO & 7.2 & 13.21 \\
$\mathbf{1 9}$ & Darfield_New Zealand & 2010 & DFHS & 7 & 11.86 \\
$\mathbf{2 0}$ & Darfield_New Zealand & 2010 & Kaiapoi North School & 7 & 30.53 \\
$\mathbf{2 1}$ & El Mayor-Cucapah_Mexico & 2010 & Westside Elementary School & 7.2 & 10.31 \\
\hline
\end{tabular}

\subsection{Structural modelling issues}

The computer program SAP2000 (Computers and Structures Inc 2013) was used to perform the NSPs and the nonlinear time history analysis (NTHA). The nonlinearity of the structural elements is modelled by employing elastic elements coupled with concentrated plastic hinges. FEMA-356 (FEMA 2000) specifies the properties of the plastic hinges at the ends of beams and columns. For columns, the interaction of axial forces and bending moments is considered. For beams, the bending moment is considered to control the formation of the hinges. For both nonlinear static and dynamic analysis, the $P-\Delta$ effect is included. The analytical solution for the NTHA was performed using the Newmark step-by-step numerical integration scheme and the Rayleigh damping was used, with a damping ratio of 5\% for the first and third modes of vibration (Chopra 2012).

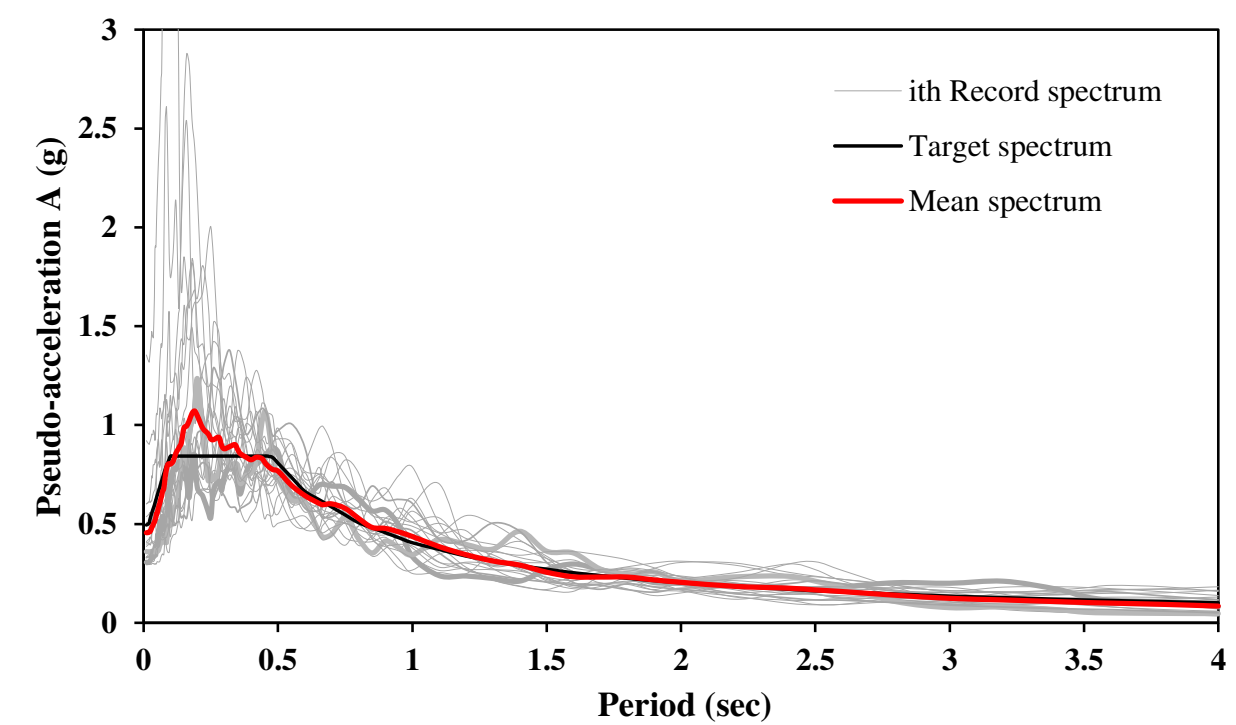

Fig. 3. Mean and individual scaled pseudo-acceleration responses spectra for the F100505 frame.

\section{Results and discussions}

The new extension of the IUB is evaluated by comparing its outcomes to those of NTHA, which are calculated as the mean values of the maximum seismic responses to the set of predefined ground motions (Table 4), in terms of target displacements, total drifts, and inter-storey drifts. For comparison purposes, results from the $1^{\text {st }}$ mode pushover, IUB (Rahmani et al. 2018), and OLLP (Habibi et al. 2019) procedures are also included.

\subsection{Preliminary results}

Table 5 presents the modal characteristics of the studied frames in terms of the period and the modal mass participation ratio for the first three modes of vibration. As seen in Table 5, the fundamental (first) period of the regular (reference) frame F101010 is the largest, while the lowest period corresponds to F100505 frame (-23.5\%). For the modal mass participation ratio, table 5 and figure 4 , illustrate the decrease of the $1^{\text {st }}$ mode ratio for the setback frames compared to the regular one. The two frames F100303 and F031003 have the smallest percentage of the 
ratio (less than 50\%). On the contrary, the increase of the modal mass participation ratio of the second mode is noticeable for the setback buildings. For instance, the mass ratio exceeds $25 \%$ for the four frames F100505, F100503, F100303 and F031003. The data in table 5 are arranged in descending order according to the value of the third mode modal mass participating ratio. Seven frames have a ratio greater than $8.5 \%$, while eight frames have a ratio smaller than $7.5 \%$. The modal mass participation ratio of the third mode can reach $10 \%$ for the F100303 and F100301 frames.

Table 5. Modal characteristics of the studied frames.

\begin{tabular}{lcccccc}
\hline \multirow{2}{*}{ Frame } & \multicolumn{3}{c}{ Periods (Sec) } & \multicolumn{3}{c}{ Modal Mass Participation Ratios (\%) } \\
\cline { 2 - 7 } & Mode 1 & Mode 2 & Mode 3 & Mode 1 & Mode 2 & Mode 3 \\
\hline F100303 & 1.43 & 0.55 & 0.36 & $49.80 \%$ & $29.30 \%$ & $10.30 \%$ \\
F100301 & 1.47 & 0.54 & 0.34 & $54.70 \%$ & $21.80 \%$ & $10.00 \%$ \\
F031003 & 1.41 & 0.55 & 0.36 & $49.60 \%$ & $30.00 \%$ & $9.90 \%$ \\
F021006 & 1.34 & 0.61 & 0.33 & $62.10 \%$ & $17.50 \%$ & $9.70 \%$ \\
F100703 & 1.33 & 0.59 & 0.36 & $65.90 \%$ & $16.00 \%$ & $8.80 \%$ \\
F031007 & 1.33 & 0.59 & 0.36 & $66.00 \%$ & $15.90 \%$ & $8.80 \%$ \\
F100603 & 1.31 & 0.61 & 0.34 & $61.20 \%$ & $20.80 \%$ & $8.50 \%$ \\
F100802 & 1.43 & 0.55 & 0.35 & $68.60 \%$ & $13.20 \%$ & $7.20 \%$ \\
F101003 & 1.57 & 0.59 & 0.36 & $67.80 \%$ & $17.50 \%$ & $6.40 \%$ \\
F100101 & 1.61 & 0.55 & 0.31 & $61.50 \%$ & $12.20 \%$ & $6.20 \%$ \\
F100503 & 1.32 & 0.61 & 0.34 & $55.40 \%$ & $27.50 \%$ & $6.20 \%$ \\
F100807 & 1.40 & 0.56 & 0.36 & $76.90 \%$ & $9.40 \%$ & $5.30 \%$ \\
F101005 & 1.52 & 0.63 & 0.34 & $70.90 \%$ & $16.40 \%$ & $4.20 \%$ \\
F101010 & 1.70 & 0.61 & 0.35 & $77.00 \%$ & $11.80 \%$ & $4.10 \%$ \\
F100505 & 1.30 & 0.65 & 0.33 & $59.90 \%$ & $25.30 \%$ & $3.90 \%$ \\
\hline
\end{tabular}

The $\left(\mathrm{q}_{\mathrm{i}} / \mathrm{q}_{1}\right)_{\mathrm{UB}}$ ratio (Figure 5) gives also information about the contribution of the second and third modes of vibration to the seismic response of the structures relative to the first mode. This ratio, which considers both the modal participation and displacement spectral amplitudes $\left(S_{d i}\right)$, shows that the contribution of the second mode is higher than the third mode for all the frames, with a ratio ranging from $15 \%$ to $30 \%$ (the maximum value belongs to the F100505 frame, and the minimum to the regular frame). However, the third mode to the first mode ratio $\left(\mathrm{q}_{3} / \mathrm{q}_{1}\right)_{\mathrm{UB}}$ exceeds $5 \%$ for ten frames (Figure 5) which the proposed method will take into account.

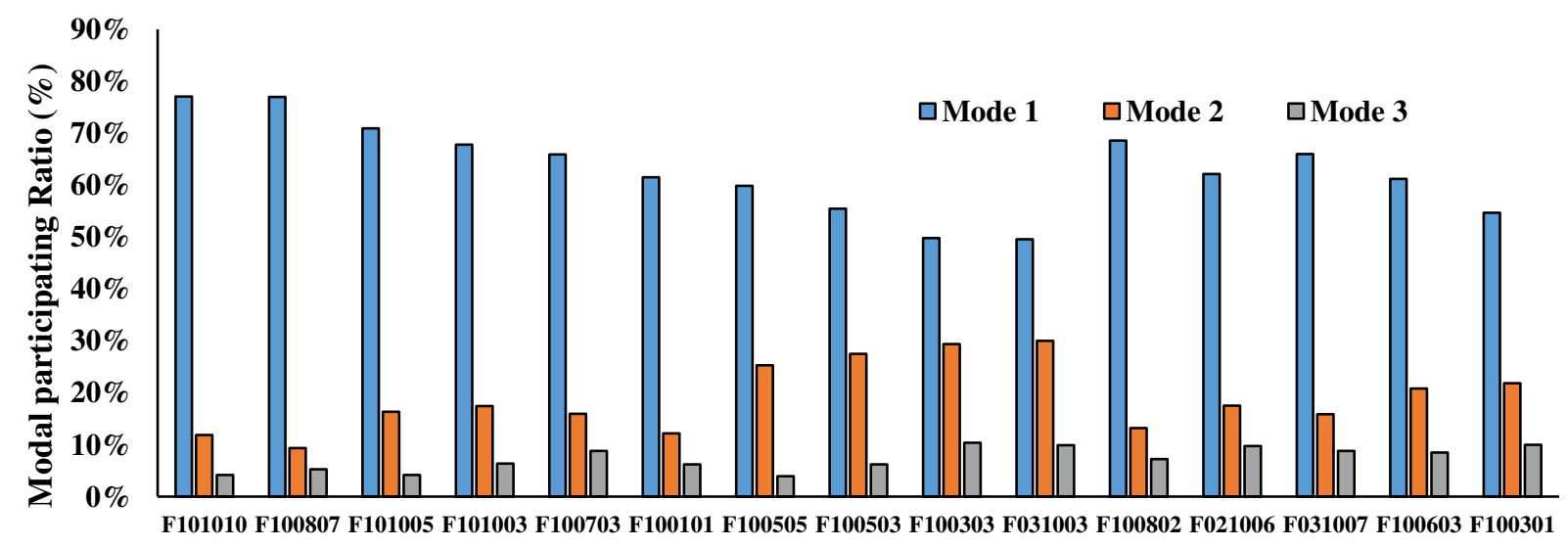

Frame

Fig. 4. Effective modal mass participation ratio for the three first modes of the studied frames. 


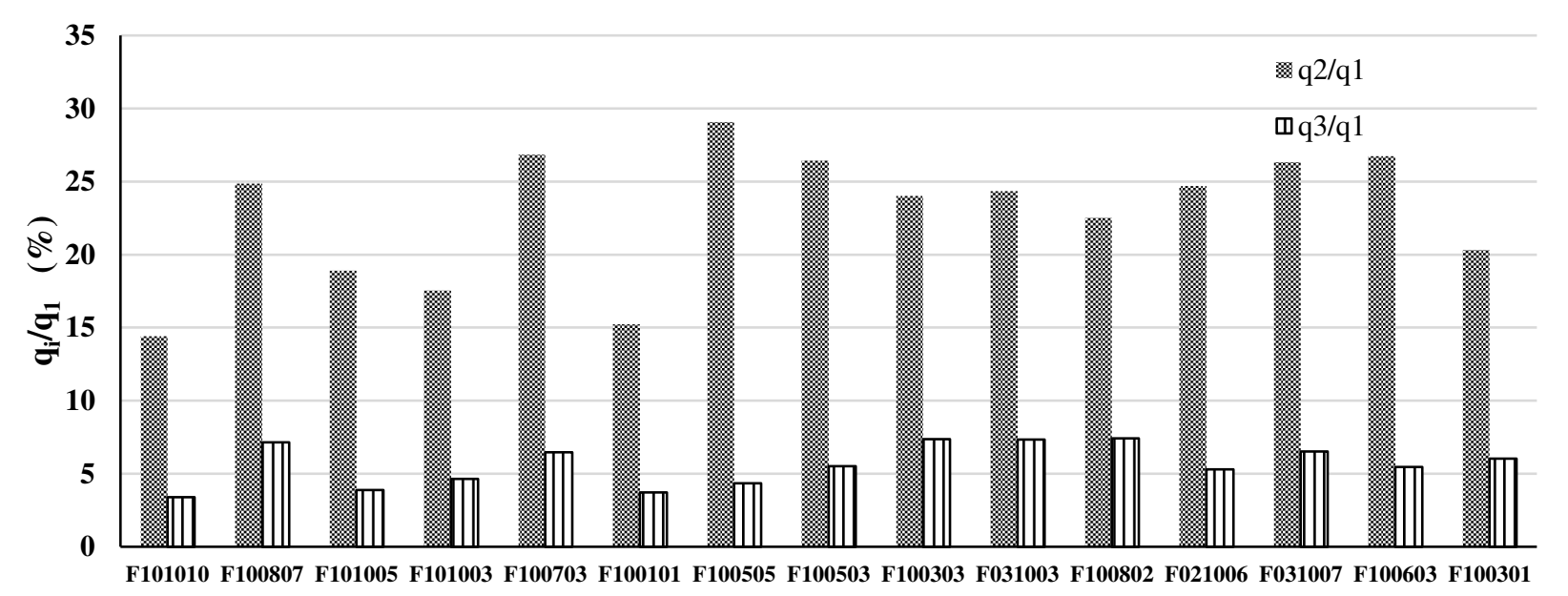

Fig. 5. The $\left(\mathrm{q}_{\mathrm{i}} / \mathrm{q}_{1}\right)_{\mathrm{UB}}$ ratio of the second and third modes of the studied frames.

\subsection{Target displacement prediction}

Table 6 shows clearly that the conventional pushover analysis with first mode lateral load distribution underestimates the target displacement and gives, in most cases, negative error values with a maximum of $9.49 \%$. The underestimation of the target displacement will affect the storey drift results $(\$ 6.4)$. The errors in estimating the target displacements range between $5 \%$ and $15.23 \%$ using the EIUB's target displacement formula (equation 18), whereas the errors resulting from the OLLP procedure vary between $1.24 \%$ and $26.54 \%$. Equation (17) gives a reasonable error for the target displacement less than those obtained by the equation (18) or the OLLP procedure. For that, the use of equation (17) is preferable to calculate the target displacement even for the EIUB procedure.

Table 6. Target displacement of the studied buildings.

\begin{tabular}{llllllllll}
\hline \multirow{2}{*}{ Frame } & \multicolumn{4}{c}{ Target Displacement $(\mathbf{c m})$} & \multicolumn{5}{c}{ Error (\%) } \\
\cline { 2 - 10 } & NTHA & Mode 1 & OLLP & IUB & EIUB & Mode 1 & OLLP & IUB & EIUB \\
\hline F100101 & 21.28 & 22.40 & 24.70 & 24.10 & 24.52 & 5.26 & 16.07 & 13.25 & 15.23 \\
F100303 & 23.74 & 21.90 & 24.20 & 24.52 & 25.33 & -7.74 & 1.95 & 3.30 & 6.71 \\
F100503 & 24.38 & 22.40 & 25.40 & 26.60 & 27.25 & -8.12 & 4.18 & 9.10 & 11.77 \\
F100505 & 25.57 & 23.50 & 27.20 & 26.91 & 27.42 & -8.10 & 6.37 & 5.24 & 7.23 \\
F100703 & 24.26 & 22.20 & 25.40 & 25.18 & 25.90 & -8.51 & 4.68 & 3.77 & 6.74 \\
F100807 & 23.63 & 22.00 & 29.90 & 24.29 & 25.06 & -6.89 & 26.54 & 2.80 & 6.06 \\
F031003 & 23.61 & 21.70 & 23.90 & 24.34 & 25.13 & -8.08 & 1.24 & 3.10 & 6.45 \\
F101003 & 21.73 & 22.50 & 25.00 & 24.47 & 24.99 & 3.53 & 15.03 & 12.59 & 14.99 \\
F101005 & 22.88 & 22.80 & 25.80 & 24.95 & 25.40 & -0.37 & 12.74 & 9.03 & 11.00 \\
F101010 & 22.59 & 23.36 & 25.80 & 25.04 & 25.43 & 3.41 & 14.21 & 10.84 & 12.57 \\
F100802 & 23.20 & 21.60 & 26.60 & 24.03 & 24.83 & -6.90 & 14.66 & 3.58 & 7.03 \\
F021006 & 24.18 & 22.30 & 26.20 & 25.05 & 25.64 & -7.78 & 8.35 & 3.60 & 6.04 \\
F031007 & 24.22 & 22.10 & 27.10 & 25.01 & 25.73 & -8.75 & 11.89 & 3.26 & 6.23 \\
F100603 & 24.97 & 22.60 & 26.50 & 25.62 & 26.24 & -9.49 & 6.13 & 2.60 & 5.09 \\
F100301 & 22.51 & 21.80 & 23.90 & 24.02 & 24.67 & -3.15 & 6.18 & 6.71 & 9.60 \\
\hline
\end{tabular}

\subsection{Total Drift prediction}

The mean total drift profiles obtained by the NTHA, as well as those derived from $1^{\text {st }}$ mode pushover, OLLP, IUB, and EIUB procedures, are presented in Figure 6. Compared to the NTHA results, OLLP underestimates the total drift at lower storeys and overestimates it at upper-storeys in most cases. The $1^{\text {st }}$ mode pushover analysis underestimates also the total drift especially at the upper-storeys for six cases. At lower storeys, the procedure can lead to a more accurate 
estimation than the OLLP procedure. The best results of the $1^{\text {st }}$ mode pushover analysis are observed for the regular frame in which the $1^{\text {st }}$ mode dominates the response according to table 5 with a modal participating mass amounts $77 \%$.
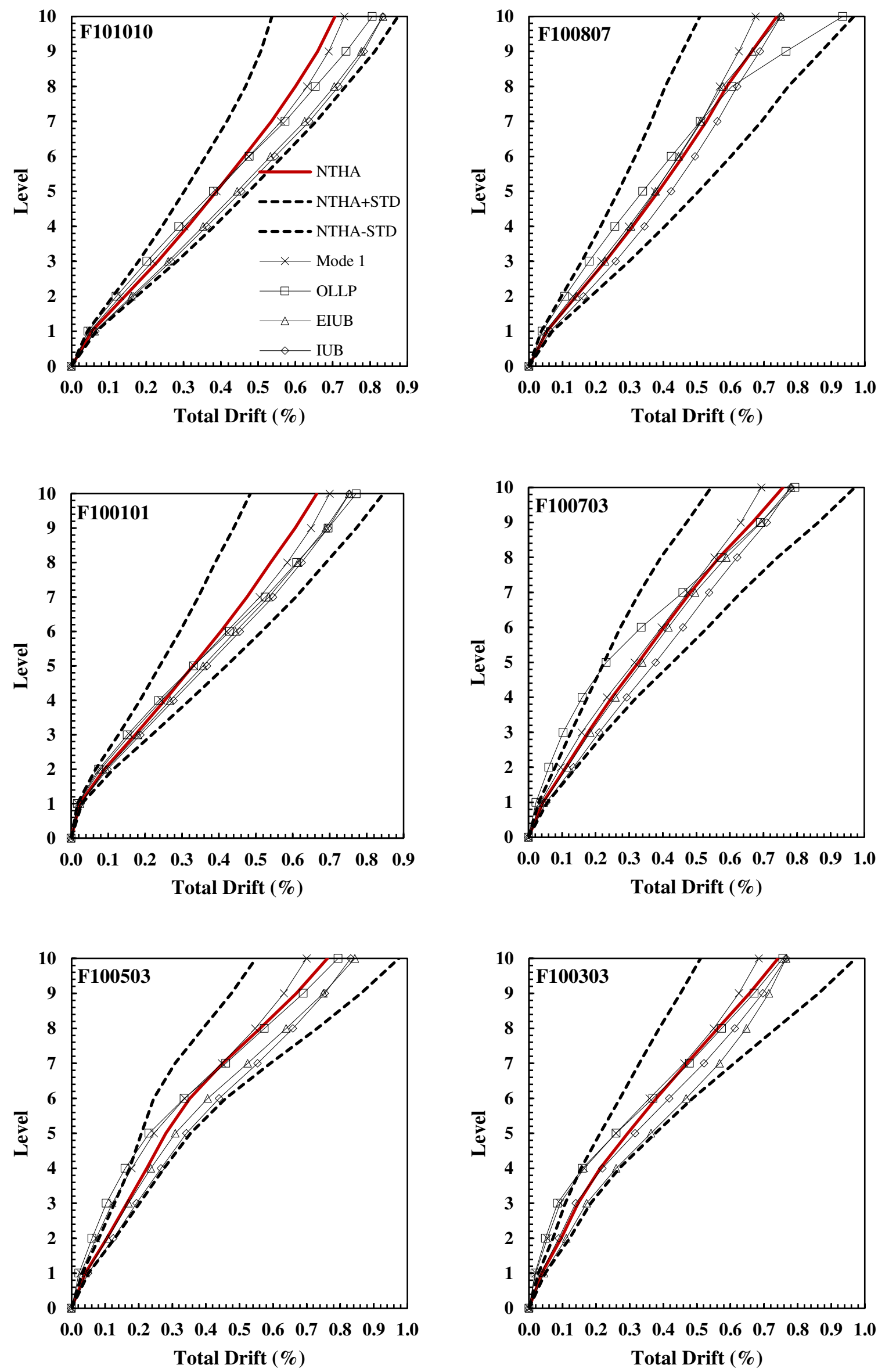

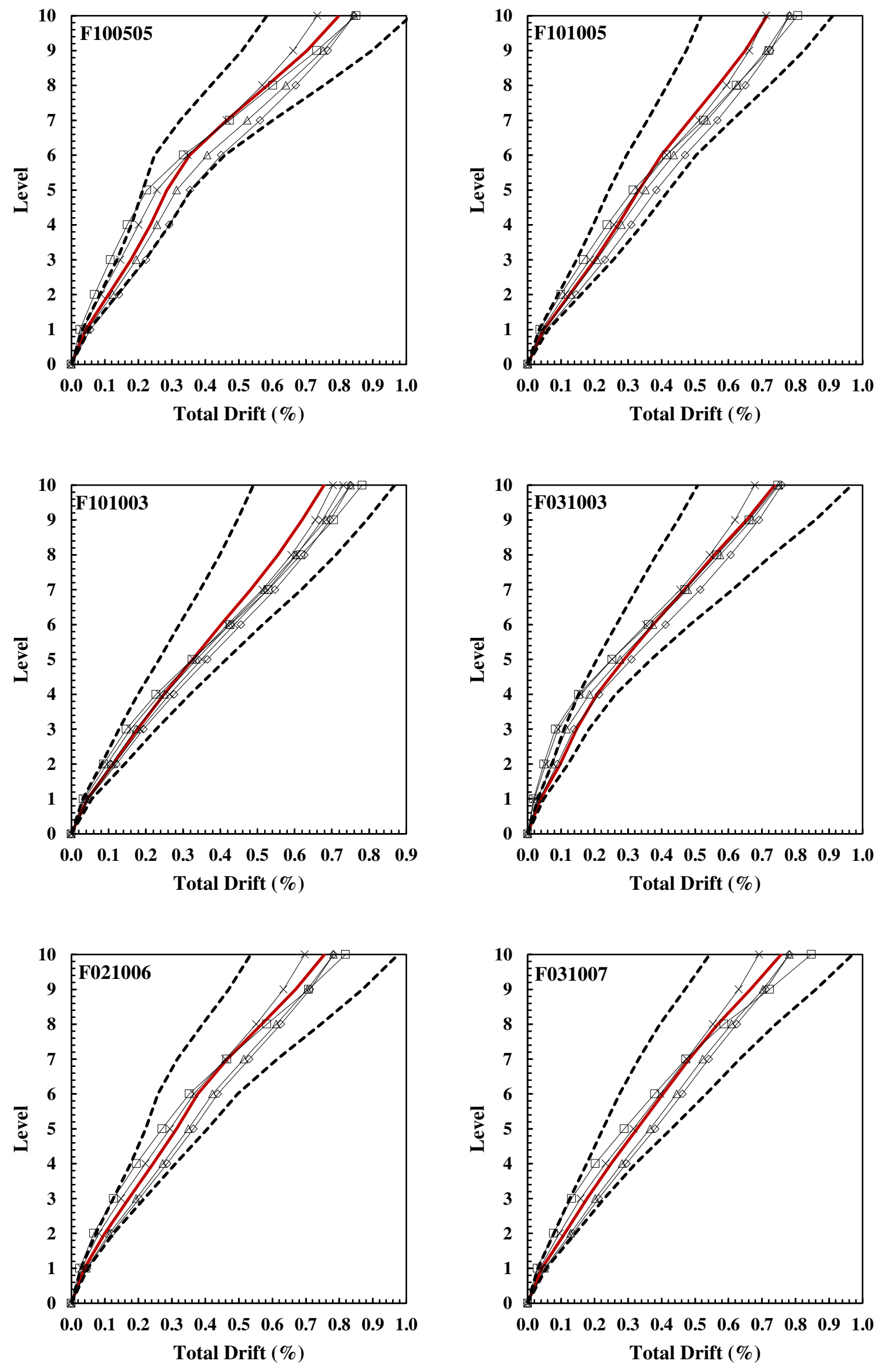

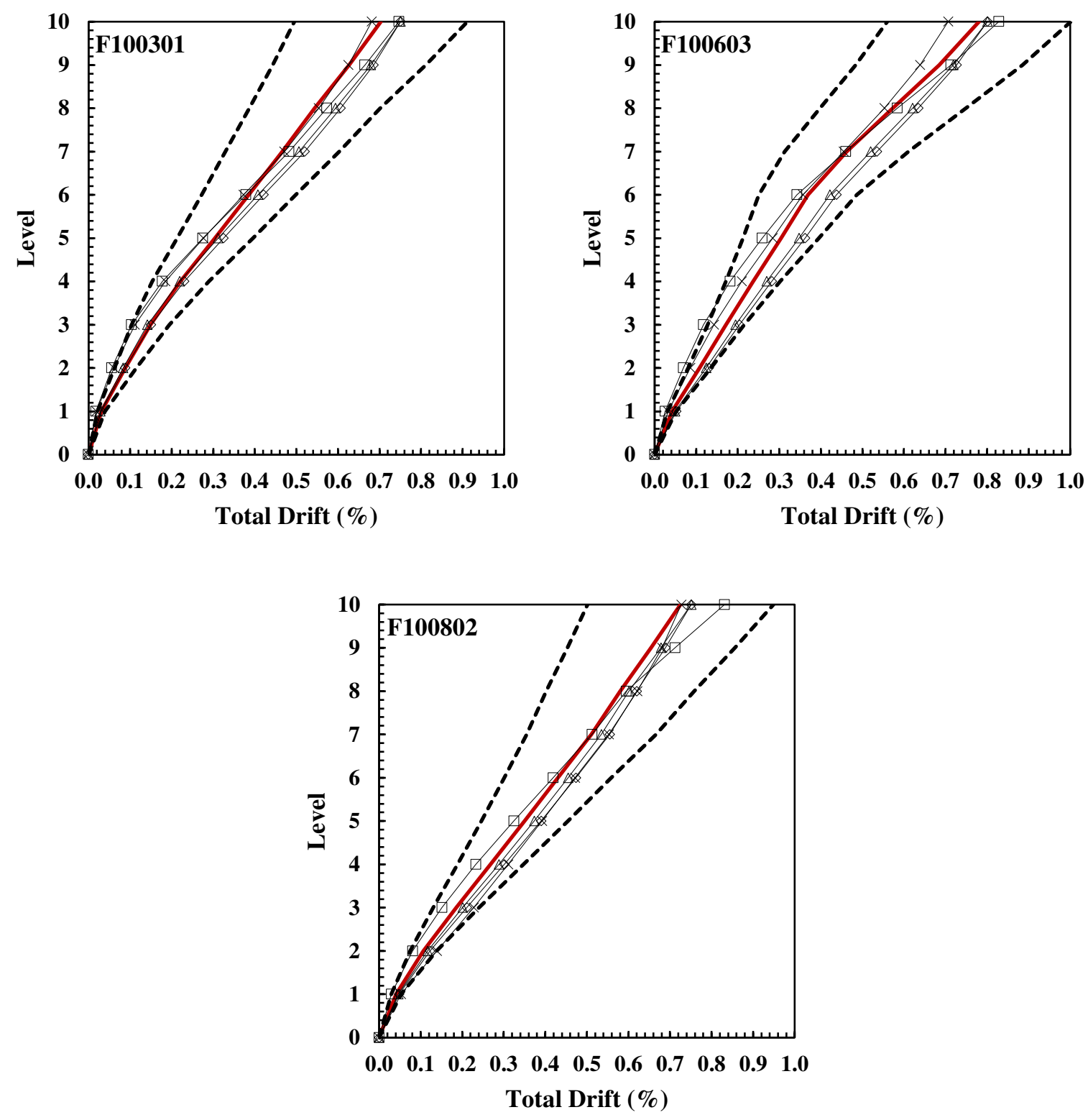

Fig. 6. Total drift of studied buildings.

It can be noticed from figure 6 that the two procedures IUB and EIUB lead to a good and safer estimation of the response.

\subsection{Storey Drift prediction}

Figure 7 presents the storey drifts predicted by the NTHA and the NSPs procedures, while figure 8 depicts the differences between the NSPs predictions and the reference values of the NTHA. Both figures confirm that the OLLP underestimates the response of all the studied frames except the regular frame F101010. The largest error in predicting the storey drift by the OLLP reached $126 \%$ for the F100807 frame. The first mode pushover analysis results are close to the NTHA results for the regular frame, but it fails to predict the response in most of the studied cases. It underestimates the lower storey drifts significantly, with a maximum error of $50.30 \%$ recorded in the F100503 frame. Moreover, this procedure underestimates also the response at the upper storey of all the setback frames. IUB and EIUB procedures provide a good estimation of the response along with the height of the studied frames. The results obtained from the IUB are closer to those of the NTHA compared to the corresponding results of the OLLP and $1^{\text {st }}$ mode pushover procedures. The storey drifts predicted by the IUB at the lower storeys are satisfactory. 
However, IUB underestimates the response at the upper storeys of the setback frames, where the error exceeds $-15 \%$ in nine cases. Figures 7 and 8 indicate that the prediction of the storey drifts has been improved using the EIUB compared to IUB results. For the upper storeys, EIUB gives a more safe estimation of the storey drifts than the IUB procedure in all cases.

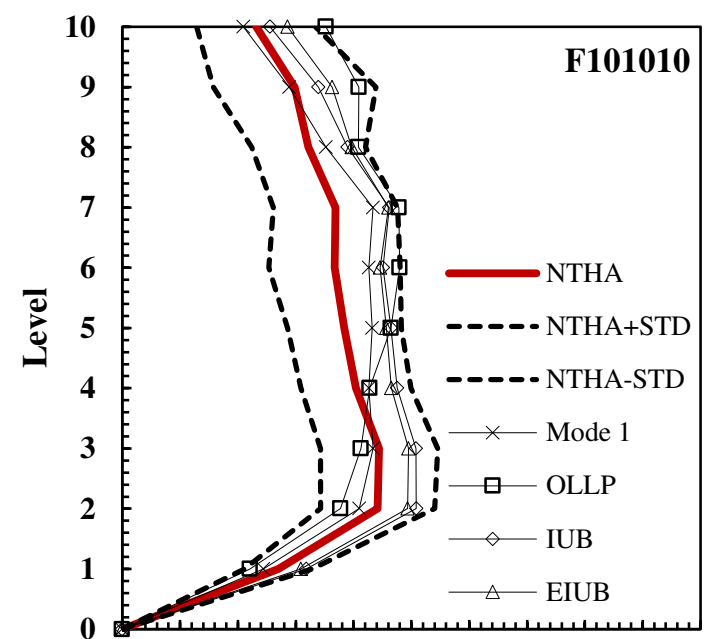

$\begin{array}{lllllllllllllll}0.0 & 0.2 & 0.4 & 0.6 & 0.8 & 1.0 & 1.2 & 1.4 & 1.6 & 1.8 & 2.0\end{array}$

Storey Drift Ratio (\%)
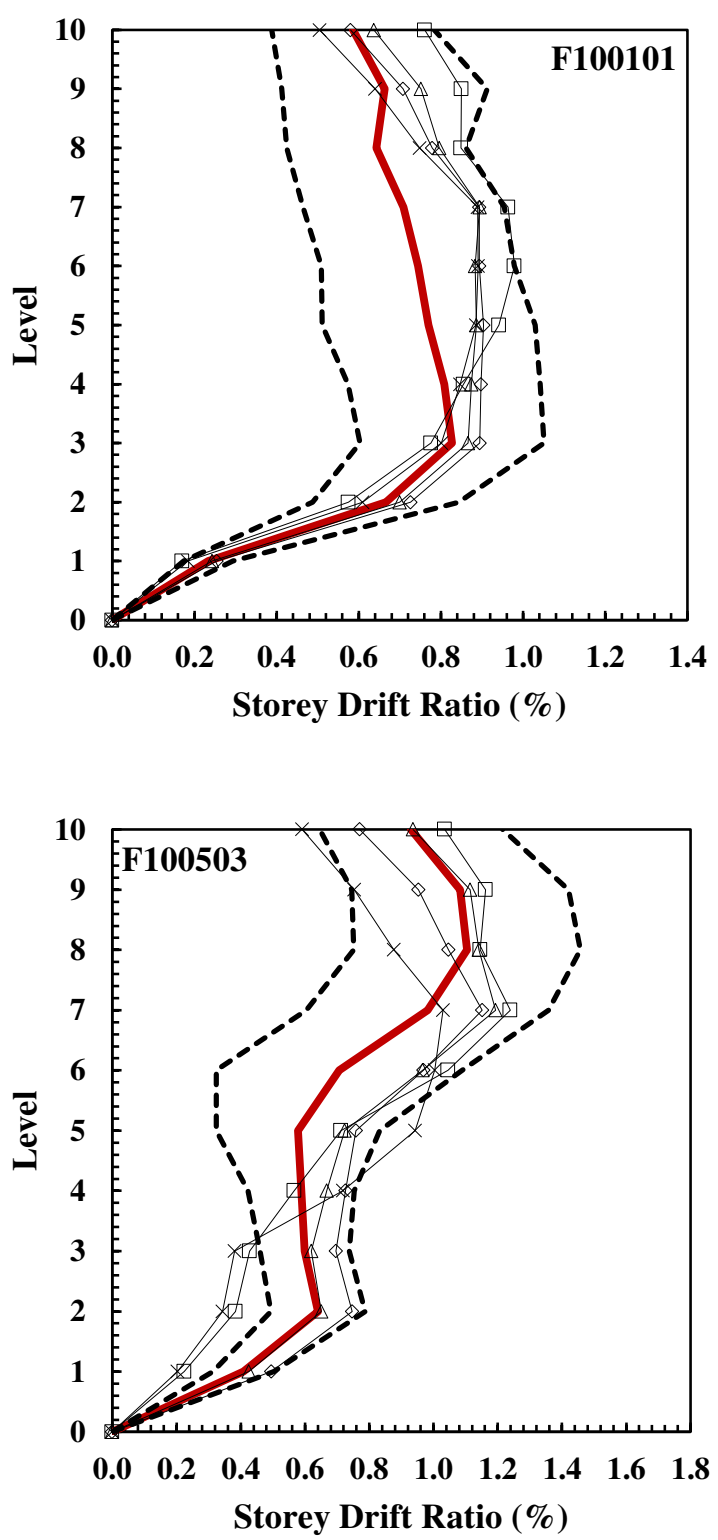
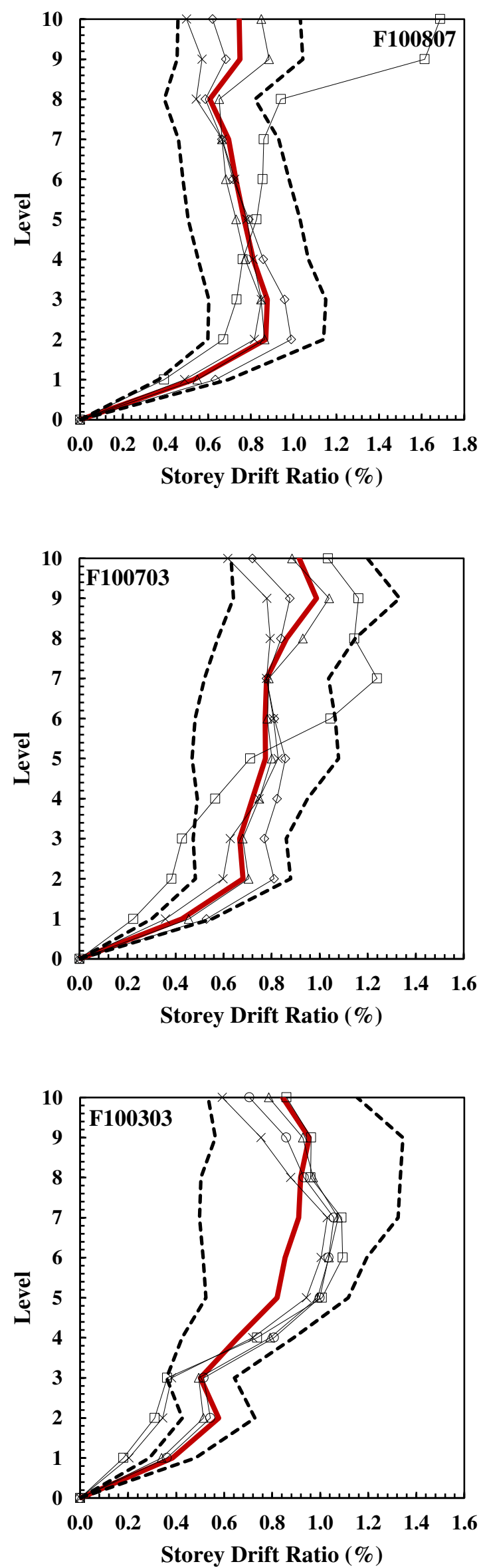

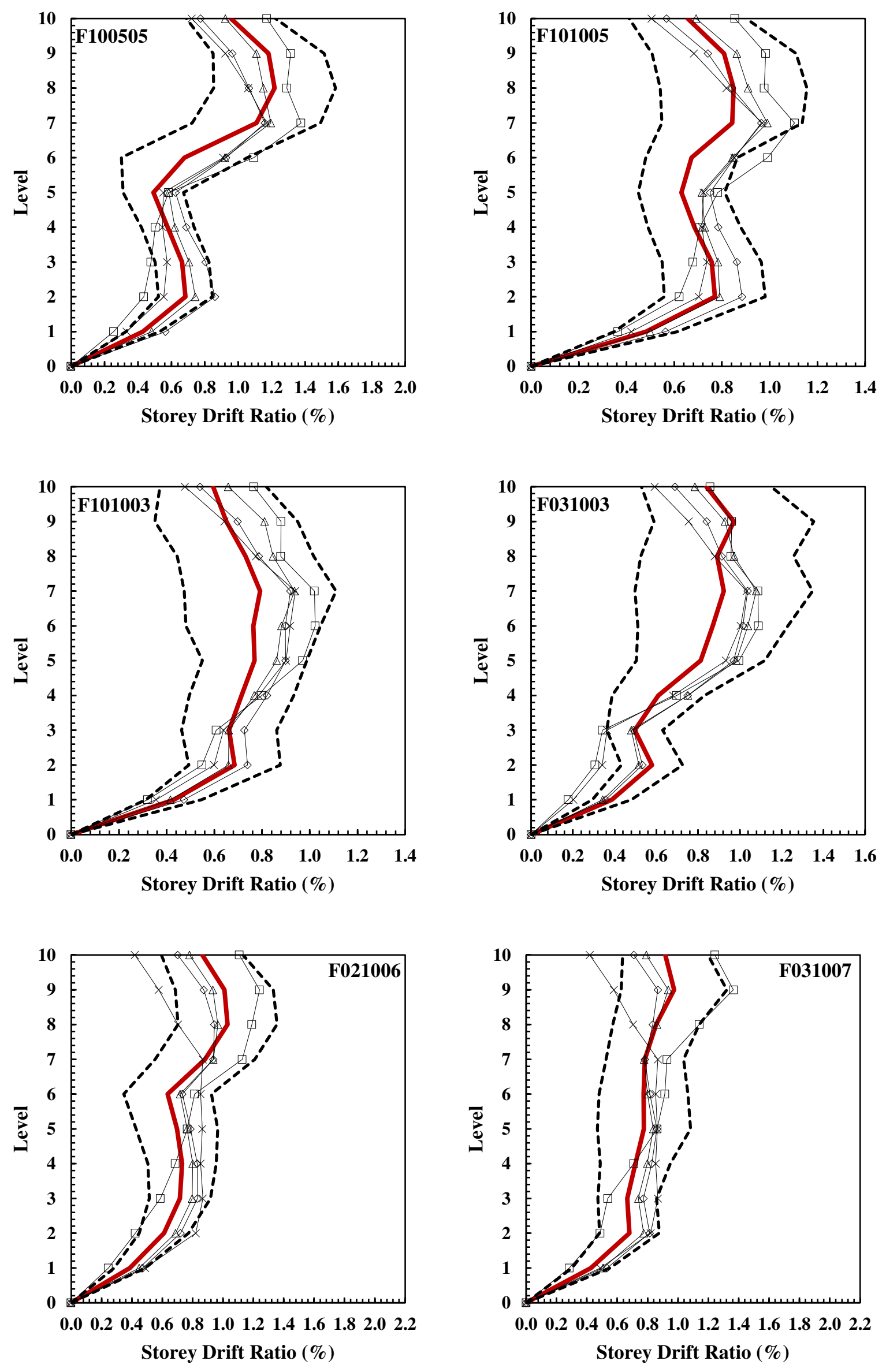

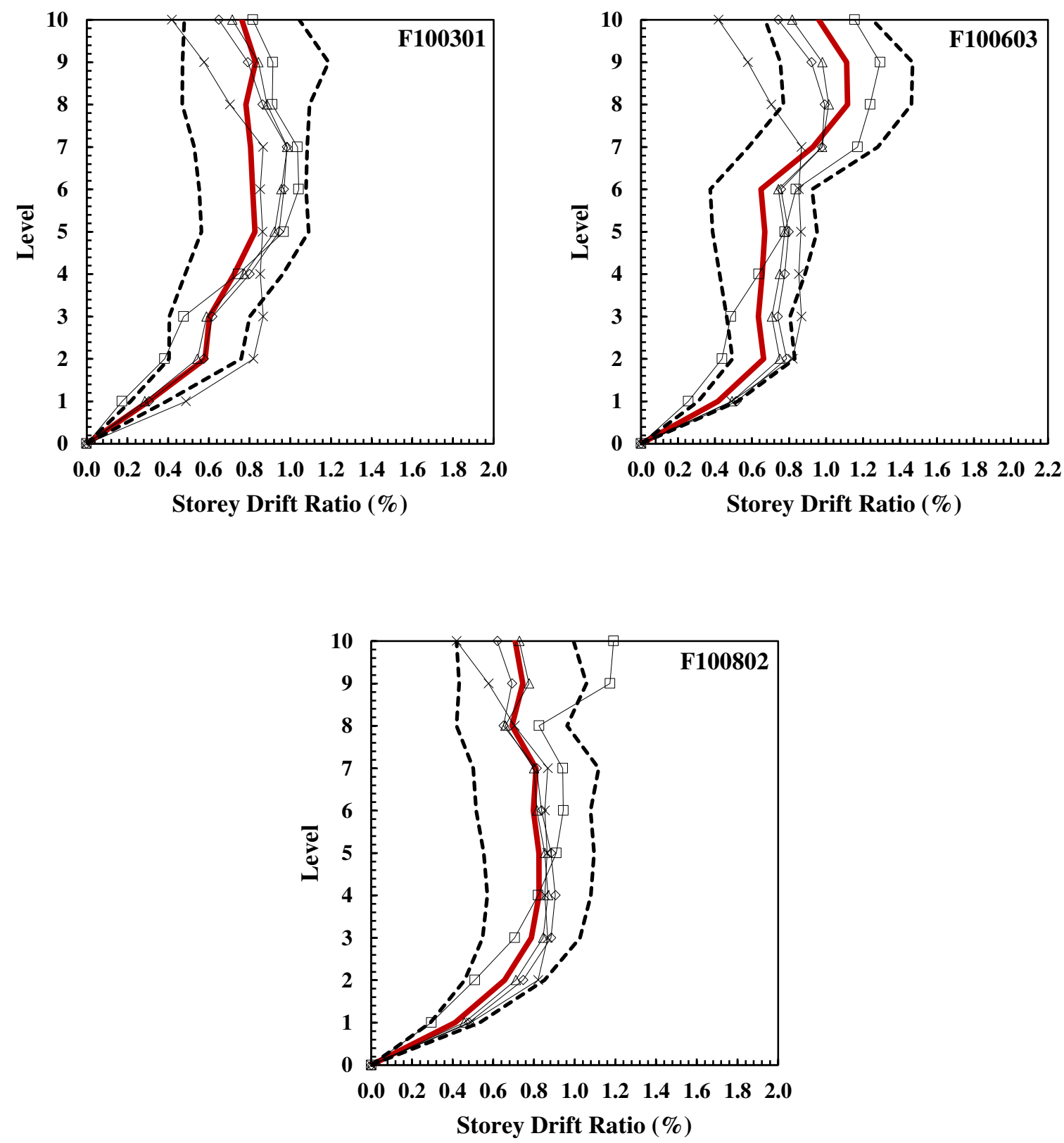

Fig. 7. Storey drift of studied buildings.
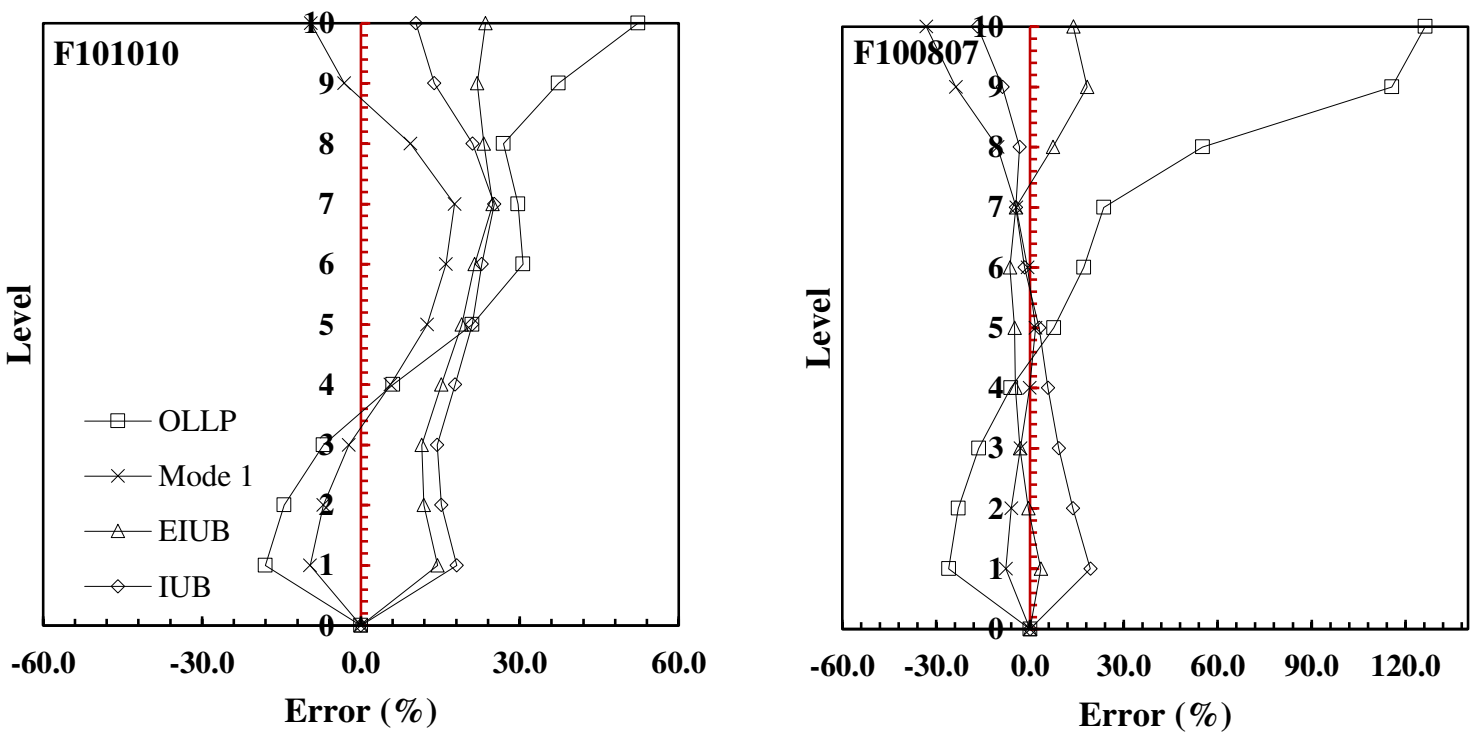

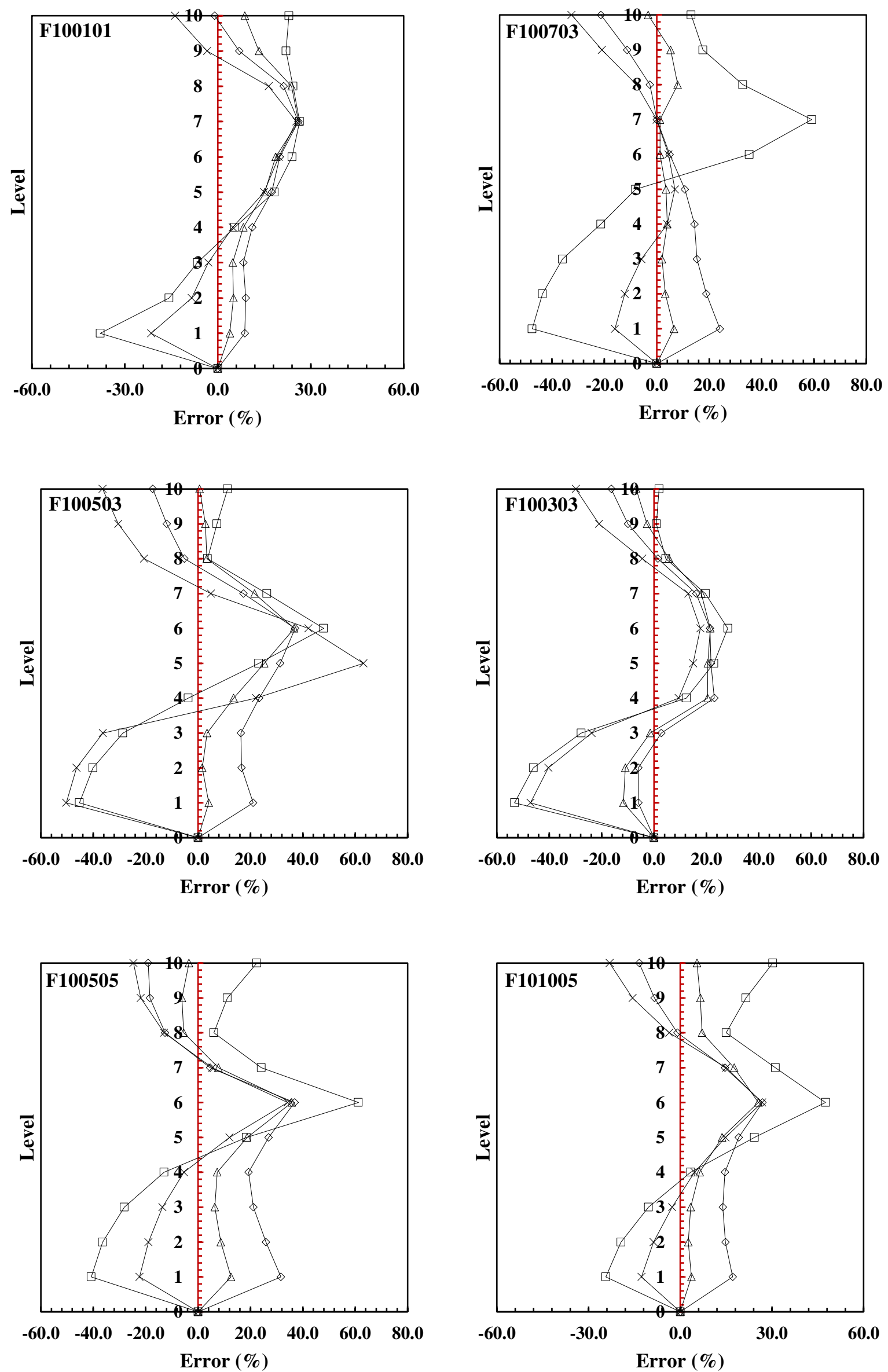

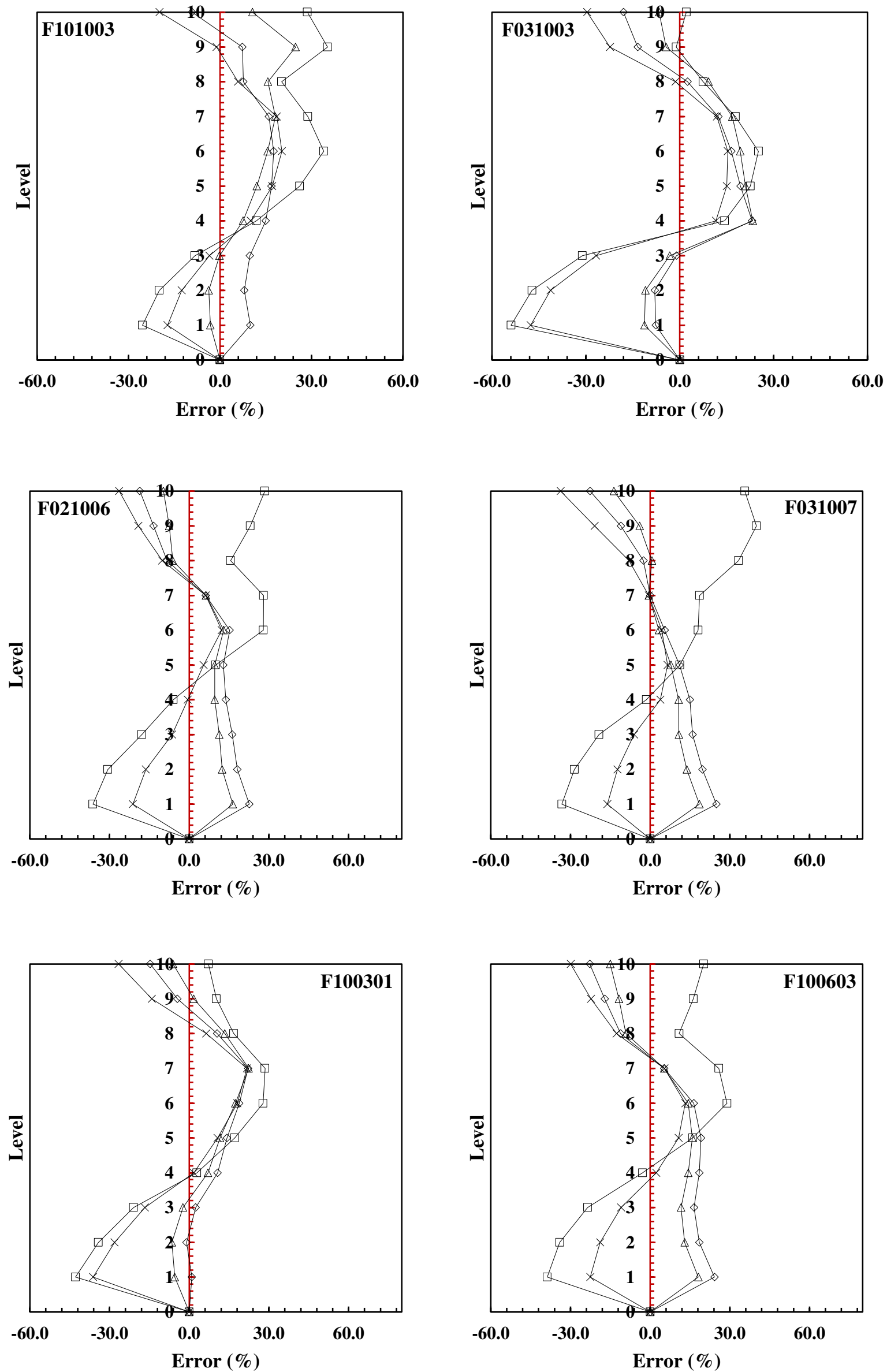


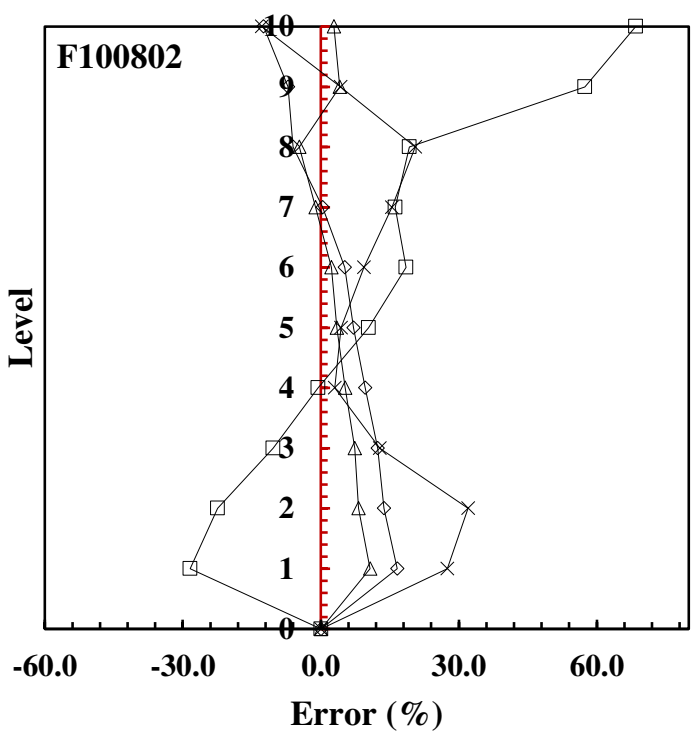

Fig. 8. Error in storey drift of studied buildings.

Figure 9 shows the mean absolute error of the storey drifts obtained by the NSPs regarding the NTHA results. EIUB procedure provides more accurate estimates of the storey drift for all the setback frames compared with the other NSPs used in this investigation. The maximum mean absolute error for the proposed procedure reached $18.71 \%$ in the case of the regular frame, this error remains less than $15 \%$ for the rest of the frames (all the studied setback frames). The mean absolute errors of the OLLP predictions exceed $20 \%$ for all models, with a maximum error of $41.68 \%$ recorded for the F100807 model. In addition, the first mode pushover analysis obtained less accurate estimations of storey drifts. The procedure cannot predict the response given large errors in three cases with an error higher than $20 \%$. IUB procedure gives errors less than the first mode pushover analysis errors in five cases, with maximum mean absolute error amounts $21.63 \%$ in the F100505 frame.

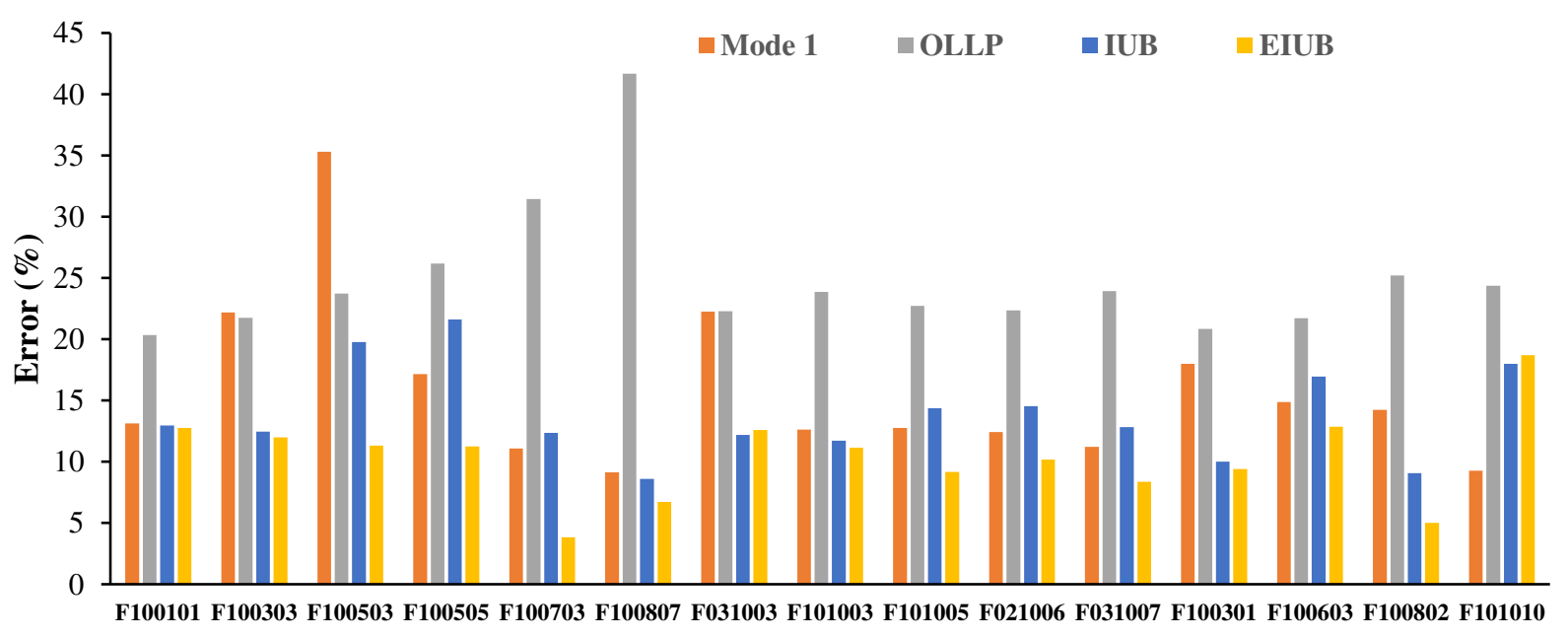

Fig. 9. Mean absolute error of the storey drifts for the studied buildings.

\section{Conclusion}

In this investigation, an extension of the so-called improved upper bound pushover analysis is developed to assess the seismic behaviour of setback buildings. The new procedure uses the first three modes of vibration to create the upper-bound lateral load vector. This vector load is 
moderated by a uniform load distribution to control the response at upper and lower storeys. Fourteen setback mid-rise steel frames were studied to validate the developed procedure. NTHA with other single-run NSPs procedures (first mode, OLLP and IUB) were used for comparison purposes. Within the limit of the small sample size of setback configurations, the evidence from this study suggests the following outcomes:

- The setback models considered in the present study show a tendency of higher modal participating mass ratio of the second mode compared to regular (reference) frame, and a consistent range of 5\% to $10 \%$ for the third mode. This tendency is maintained for the $\left(\mathrm{q}_{\mathrm{i}} / \mathrm{q}_{1}\right)_{\mathrm{UB}}$ ratio, which integrates the spectral displacement amplitudes

- Because the first mode of vibration dominates the response in regular mid-rise buildings, the first mode pushover analysis gives better results than the other advanced single run procedures. However, the proposed procedure can give safer results in this case.

- The storey drifts predicted by the IUB are closer to those from NTHA compared to the corresponding results of the OLLP and $1^{\text {st }}$ mode pushover procedures. However, IUB underestimates the response at the upper storeys of the setback frames.

- The proposed EIUB procedure improved the results of the IUB procedure in most of the setback frames, especially at the upper storeys, and gave better results than the other pushover procedures used in this study.

It is worth noting that the findings of the present study were obtained for fourteen frames with different setback configurations. However, in order to generalise the conclusions of this study, other analyses should be done for various types of irregularities.

\section{References}

Abbasnia R, Davoudi AT, Maddah MM (2014a) An Improved Displacement-Based Adaptive Pushover Procedure for the Analysis of Frame Buildings. J Earthq Eng 18:987-1008. https://doi.org/10.1080/13632469.2014.919242

Abbasnia R, Tajik Davoudi A, Maddah MM (2014b) An improved displacement-based adaptive pushover procedure based on factor modal combination rule. Earthq Eng Eng Vib 13:223241. https://doi.org/10.1007/S11803-014-0226-0

Amini MM, Poursha M (2017) Prediction the seismic demands of tall buildings using an adaptive force-based multi-mode pushover analysis. In: Proceedings of international Conference on Earthquake Engineering and Structural Dynamics. Reykjavik, Iceland

Antoniou S, Pinho R (2004a) Advantages and Limitations of Adaptive and Non-Adaptive ForceBased Pushover Procedures. J Earthq Eng 8:497-522. https://doi.org/10.1080/13632460409350498

Antoniou S, Pinho R (2004b) Development and Verification of a Displacement-Based Adaptive Pushover Procedure. J Earthq Eng 8:643-661. https://doi.org/10.1080/13632460409350504

Aranda G (1984) Ductility demands for R/C frames irregular in elevation. In: Proceedings of the eighth world conference on earthquake engineering

ASCE (2016) Minimum Design Loads for Buildings and Other Structures ASCE7-16

ATC-40 (1996) Seismic Evaluation and retrofit of concrete buildings. Appl Technol Counc Calif 1 and 2:1996

Athanassiadou CJ (2008) Seismic performance of R/C plane frames irregular in elevation. Eng Struct 30:1250-1261. https://doi.org/10.1016/J.ENGSTRUCT.2007.07.015 
Behnamfar F, Taherian SM, Sahraei A (2016) Enhanced nonlinear static analysis with the drift pushover procedure for tall buildings. Bull Earthq Eng 14:3025-3046. https://doi.org/10.1007/S10518-016-9932-5

Belejo A, Bento R (2016) Improved Modal Pushover Analysis in seismic assessment of asymmetric plan buildings under the influence of one and two horizontal components of ground motions. Soil Dyn Earthq Eng 87:1-15. https://doi.org/10.1016/j.soildyn.2016.04.011

Bohlouli Z, Poursha M (2016) Seismic evaluation of geometrically irregular steel moment resisting frames with setbacks considering their dynamic characteristics. Bull Earthq Eng 14:2757-2777. https://doi.org/10.1007/S10518-016-9910-Y

Bosco M, Ghersi A, Marino E, Rossi P (2002) Effects of in elevation irregularity on the elastic seismic response of in-plan asymmetric buildings. In: Proceedings of the Third European Workshop on the Seismic Behavior of Irregular and Complex Structures. Florence

Bracci JM, Kunnath SK, Reinhorn AM (1997a) Seismic Performance and Retrofit Evaluation of Reinforced Concrete Structures. J Struct Eng 123:3-10. https://doi.org/10.1061/(ASCE)0733-9445(1997)123:1(3)

Bracci JM, Kunnath SK, Reinhorn AM (1997b) Seismic Performance and Retrofit Evaluation of Reinforced Concrete Structures. J. Struct. Eng. 123:3-10

Chopra AK (2012) Dynamics of structures: theory and applications to earthquake engineering, 4th editio. Prentice Hall, Hong Kong

Chopra AK, Goel RK (2002) A modal pushover analysis procedure for estimating seismic demands for buildings. Earthq Eng Struct Dyn 31:561-582. https://doi.org/10.1002/eqe. 144

Chopra AK, Goel RK (2004) A modal pushover analysis procedure to estimate seismic demands for unsymmetric-plan buildings. Earthq Eng Struct Dyn 33:903-927. https://doi.org/10.1002/EQE.380

Computers and Structures Inc (2013) SAP2000NL

Das S, Nau M (2003) Seismic design aspects of vertically irregular reinforced concrete buildings. Earthq Spectra 3:455-477

Davoudi AT, Abbasnia R, Sarvghad-Moghadam A, et al (2016) An alternative modal combination rule for adaptive pushover analysis. Struct Des Tall Spec Build 25:325-339. https://doi.org/10.1002/TAL.1260

El-Esnawy N, Mahmoud BEH, Fouad AG (2020) Pushover Analysis of RC Building Frames With Symmetrical Setback | Request PDF. J Adv Sci 28:828-844

Elnashai AS. (2001) Advanced inelastic static (pushover) analysis for earthquake applications. Struct Eng Mech 12:51-69. https://doi.org/10.12989/SEM.2001.12.1.051

Fajfar P (1999) Capacity spectrum method based on inelastic demand spectra. Earthq Eng Struct Dyn 28:979-993. https://doi.org/10.1002/(SICI)1096-9845(199909)28:9<979::AIDEQE850>3.0.CO;2-1

Fajfar P, Marusic D, Perus I (2005) Torsional Effects in the Pushover-Based Seismic Analysis of Buildings. J Earthq Eng 9:831-854. https://doi.org/10.1080/13632460509350568

FEMA (2000) Prestandard and commentary for the seismic rehabilitation of buildings. Washington (DC)

Freeman SA (1998) Development and use of capacity spectrum method. Proc. 6th US NCEE Conf. Earthq. Eng. 12

Fujii K (2019) Prediction of the Maximum Seismic Member Force in a Superstructure of a BaseIsolated Frame Building by Using Pushover Analysis. Build 9:201. 
https://doi.org/10.3390/BUILDINGS9090201

Guan M, Liu W, Du H, et al (2019) Combination model for conventional pushover analysis considering higher mode vibration effects. Struct Des Tall Spec Build 28:e1625. https://doi.org/10.1002/TAL.1625

Habibi A, Saffari H, Izadpanah M (2019) Optimal lateral load pattern for pushover analysis of building structures. Steel Compos Struct 32:67-77. https://doi.org/10.12989/SCS.2019.32.1.067

Humar J, Wright E (1977) Earthquake response of steel framed multi-storey buildings with setbacks. Earthq Eng Struct Dyn 1:15-39

Jalilkhani M, Ghasemi SH, Danesh M (2020) A multi-mode adaptive pushover analysis procedure for estimating the seismic demands of RC moment-resisting frames. Eng Struct 213:110528. https://doi.org/10.1016/J.ENGSTRUCT.2020.110528

Jan TS, Liu MW, Kao Ying Chieh C (2004) An upper-bound pushover analysis procedure for estimating the seismic demands of high-rise buildings. Eng Struct 26:117-128. https://doi.org/10.1016/J.ENGSTRUCT.2003.09.003

Kalkan E, Kunnath SK (2006a) Adaptive Modal Combination Procedure for Predicting Seismic Response of Vertically Irregular Structural Systems. ... US Natl Conf Earthq ...

Kalkan E, Kunnath SK (2006b) Adaptive Modal Combination Procedure for Nonlinear Static Analysis of Building Structures. J Struct Eng 132:1721-1731. https://doi.org/10.1061/(ASCE)0733-9445(2006)132:11(1721)

Khoshnoudian F, Kiani M (2012) Modified consecutive modal pushover procedure for seismic investigation of one-way asymmetric-plan tall buildings. Earthq Eng Eng Vib 2012112 11:221-232. https://doi.org/10.1007/S11803-012-0112-6

Kreslin M, Fajfar P (2011a) The extended N2 method taking into account higher mode effects in elevation. Earthq Eng Struct Dyn 40:1571-1589. https://doi.org/10.1002/EQE.1104

Kreslin M, Fajfar P (2011b) The extended N2 method considering higher mode effects in both plan and elevation. Bull Earthq Eng 10:695-715. https://doi.org/10.1007/S10518-0119319-6

Lignos D, Gantes C (2005) Seismic demands for steel braced frames with stiffness irregularities based on modal pushover analysis. In: Proceedings of the 4th European Workshop on the Seismic Behavior of Irregular and Complex Structures. Thessaloniki

Liu Y, Kuang JS (2017) Spectrum-based pushover analysis for estimating seismic demand of tall buildings. Bull Earthq Eng 15:4193-4214. https://doi.org/10.1007/S10518-017-0132-8

Liu Y, Kuang JS, Huang Q (2018) Extended spectrum-based pushover analysis for predicting earthquake-induced forces in tall buildings. Eng Struct 167:351-362. https://doi.org/10.1016/J.ENGSTRUCT.2018.04.045

Liu Y, Kuang JS, Huang Q, et al (2020) Spectrum-based pushover analysis for the quick seismic demand estimation of reinforced concrete shear walls. Structures 27:1490-1500. https://doi.org/10.1016/J.ISTRUC.2020.07.040

Mao J, Zhai C, Xie L (2008) An improved modal pushover analysis procedure for estimating seismic demands of structures. Earthq Eng Eng Vib 7:25-31. https://doi.org/10.1007/s11803-008-0786-y

Mazzolani F, Piluso V (1996) Theory and design of seismic resistant steel frames. FN \& SPON an Imprint of Chapman \& Hall, London

Paraskeva TS, Kappos AJ (2010) Further development of a multimodal pushover analysis procedure for seismic assessment of bridges. Earthq Eng Struct Dyn 39:211-222. 
https://doi.org/10.1002/EQE.947

Pinto D, Costa A (1995) Influence of Vertical Irregularities on Seismic Response of Buildings. In: Proceedings of the Tenth European Conference on Earthquake Engineering. Rotterdam

Poursha M, Amini MA (2015) A single-run multi-mode pushover analysis to account for the effect of higher modes in estimating the seismic demands of tall buildings. Bull Earthq Eng 13:2347-2365. https://doi.org/10.1007/S10518-014-9721-Y

Poursha M, Khoshnoudian F, Moghadam a. S (2014) The extended consecutive modal pushover procedure for estimating the seismic demands of two-way unsymmetric-plan tall buildings under influence of two horizontal components of ground motions. Soil Dyn Earthq Eng 63:162-173. https://doi.org/10.1016/j.soildyn.2014.02.001

Poursha M, Khoshnoudian F, Moghadam AS (2009) A consecutive modal pushover procedure for estimating the seismic demands of tall buildings. Eng Struct 31:591-599. https://doi.org/10.1016/J.ENGSTRUCT.2008.10.009

Poursha M, Samarin ET (2015) The modified and extended upper-bound (UB) pushover method for the multi-mode pushover analysis of unsymmetric-plan tall buildings. Soil Dyn Earthq Eng 71:114-127. https://doi.org/10.1016/j.soildyn.2015.01.012

Rahmani AY, Bourahla N, Bento R, Badaoui M (2019a) Adaptive upper-bound pushover analysis for high-rise moment steel frames. Structures 20:912-923. https://doi.org/10.1016/J.ISTRUC.2019.07.006

Rahmani AY, Bourahla N, Bento R, Badaoui M (2018) An improved upper-bound pushover procedure for seismic assessment of high-rise moment resisting steel frames. Bull Earthq Eng 16:. https://doi.org/10.1007/s10518-017-0204-9

Rahmani AY, Bourahla N, Bento R, Badaoui M (2019b) Adaptive upper-bound pushover analysis for high-rise moment steel frames. Structures 20: https://doi.org/10.1016/j.istruc.2019.07.006

Reyes JC, Chopra AK (2011) Three-dimensional modal pushover analysis of buildings subjected to two components of ground motion, including its evaluation for tall buildings. Earthq Eng Struct Dyn 40:789-806. https://doi.org/10.1002/EQE.1060

Romão X, Costa A, Delgado R (2004) SEISMIC BEHAVIOR OF REINFORCED CONCRETE FRAMES WITH SETBACKS. In: 13th World Conference on Earthquake Engineering. Vancouver, B.C., Canada

Rooshenas A (2020) Comparing pushover methods for irregular high-rise structures, partially infilled with masonry panels. Structures 28:337-353. https://doi.org/10.1016/J.ISTRUC.2020.08.073

Sahraei A, Behnamfar F (2014) A Drift Pushover Analysis Procedure for Estimating the Seismic Demands of Buildings: Earthq Spectra 30:1601-1618. https://doi.org/10.1193/030811EQS038M

Sarkar P, Prasad AM, Menon D (2010) Vertical geometric irregularity in stepped building frames. Eng Struct 32:2175-2182. https://doi.org/10.1016/J.ENGSTRUCT.2010.03.020

Shahrooz BM, Moehle JP (1990) Seismic response and design of setback buildings. J Struct Eng 5:1423-1439

Shakeri K, Shayanfar MA, Kabeyasawa T (2010a) A story shear-based adaptive pushover procedure for estimating seismic demands of buildings. Eng Struct 32:174-183. https://doi.org/10.1016/J.ENGSTRUCT.2009.09.004

Shakeri K, Shayanfar MA, Kabeyasawa T (2010b) A story shear-based adaptive pushover procedure for estimating seismic demands of buildings. Eng Struct 32:174-183. https://doi.org/10.1016/j.engstruct.2009.09.004 
Shakeri K, Tarbali K, Mohebbi M (2013) Modified Adaptive Modal Combination Procedure for Nonlinear Static Analysis of Bridges. http://dx.doi.org/101080/136324692013781558 17:918-935. https://doi.org/10.1080/13632469.2013.781558

Sürmeli M, Yüksel E (2018) An adaptive modal pushover analysis procedure (VMPA-A) for buildings subjected to bi-directional ground motions. Bull Earthq Eng 16:5257-5277. https://doi.org/10.1007/S10518-018-0324-X

Tarbali K, Shakeri K (2014) Story shear and torsional moment-based pushover procedure for asymmetric-plan buildings using an adaptive capacity spectrum method. Eng Struct 79:3244. https://doi.org/10.1016/J.ENGSTRUCT.2014.08.006

Wong C, Tso W (1994) Seismic loading for buildings with setbacks. Can J Civ Eng 5:863-871

Wood S (1992) Seismic response of R/C frames with irregular Profiles. J Struct Eng 118:545566

Zarrin M, Mostafa Gharabaghi AR, Poursha M (2021a) A multi-mode N2 (MN2) pushover procedure for ductility level seismic performance evaluation of jacket type offshore platforms. Ocean Eng 220:108440. https://doi.org/10.1016/J.OCEANENG.2020.108440

Zarrin M, Poursha M, Gharabaghi ARM (2021b) An updated consecutive modal pushover (UCMP) procedure for estimating the ductility level earthquake design demands of jacket offshore platforms. Soil Dyn Earthq Eng 145:106680. https://doi.org/10.1016/J.SOILDYN.2021.106680

PEER ground motion database (2021). In: PEER Gr. motion database. https://ngawest2.berkeley.edu

\section{Statements and Declarations}

Conflicts of interest: The authors declare that there is no conflict of interests regarding the publication of this paper

Funding: Research for this paper was conducted with partial MERS (Ministry of higher education in Algeria) support under Grant PRFU A01L02ES160220190001.

Data availability: The data that support the fndings of this study are available from the corresponding author, Abdallah Yacine Rahmani, upon reasoned request. 